\title{
Eugenol and Lippia Alba Essential Oils as Effective Anesthetics for the Amazonian Freshwater Stingray Potamotrygon Wallacei (Chondrichthyes, Potamotrygonidae)
}

Cristiano Lopes de Lima

Instituto Federal de Educação Ciência e Tecnologia do Amazonas: Instituto Federal de Educacao

Ciencia e Tecnologia do Amazonas

Ruben Dario Morales-Gamba

UFAM: Universidade Federal do Amazonas

Thiago Santana Malcher Neto

Instituto Federal de Educação Ciência e Tecnologia do Amazonas: Instituto Federal de Educacao Ciencia e Tecnologia do Amazonas

José Fernando Marques Barcellos

UFAM: Universidade Federal do Amazonas

\section{Berta Maria Heinzmann}

UFSM: Universidade Federal de Santa Maria

Denise Schmidt

UFSM: Universidade Federal de Santa Maria

\section{Bernardo Baldisserotto}

UFSM: Universidade Federal de Santa Maria

JAYDIONE LUIZ MARCON ( $\boldsymbol{\nabla}$ jlmarcon@ufam.edu.br)

Universidade Federal do Amazonas https://orcid.org/0000-0001-5141-7816

\section{Research Article}

Keywords: anesthesia, animal health, elasmobranchs, gill histology, natural anesthetics, physiological responses.

Posted Date: September 1st, 2021

DOl: https://doi.org/10.21203/rs.3.rs-852948/v1

License: (c) (1) This work is licensed under a Creative Commons Attribution 4.0 International License. Read Full License 
Version of Record: A version of this preprint was published at Fish Physiology and Biochemistry on November 22nd, 2021. See the published version at https://doi.org/10.1007/s10695-021-01029-1. 


\section{Abstract}

This study assessed the potential of eugenol and the essential oil of Lippia alba (EOLA) in providing suitable anesthetic induction and recovery times, and their consequent effects on the blood and respiratory physiology, as well as the gill architecture of an Amazonian freshwater stingray, Potamotrygon wallacei, at the onset of the anesthetic event and after $48 \mathrm{~h}$ of recovery. Juveniles of $P$. wallacei $(\mathrm{n}=12)$ were exposed to increasing concentrations of eugenol $\left(75,100,125\right.$ and $\left.150 \mu \mathrm{L} \mathrm{L}^{-1}\right)$ and EOLA $\left(150,175,200\right.$ and $\left.225 \mu \mathrm{L} \mathrm{L}^{-1}\right)$ in an immersion bath. Anesthetic induction was found to be faster with the use of eugenol compared to EOLA. On the other hand, the stingrays anesthetized with eugenol displayed a longer recovery time than those exposed to EOLA. The highest concentrations of eugenol caused moderate to severe histological changes in the gills. No significant changes were found for hematocrit and plasma metabolites in the stingrays anesthetized with all concentrations of both eugenol and EOLA just after the onset of anesthetic action, when compared to those recovered after 48 hours. Investigations regarding the potential use of these natural anesthetics are unprecedented for freshwater stingray species and $200 \mu \mathrm{L} \mathrm{L}^{-1}$ EOLA is recommended as the most suitable anesthetic for use in juveniles of $P$. wallacei.

\section{Introduction}

Regardless of the experience of researchers, physiologists and other professionals in activities that involve the restraint and immobilization of elasmobranch fishes, the required ability to perform scientific assessments, surgical procedures or collection of biological samples is not a trivial practice. Due to the high risk of accidents, the use of anesthetics is a fundamental procedure to provide safe handling and mitigate the consequent stress to the animal. The use of anesthetics during research practices allows the manipulation of these animals more safely since the presence of stingers with toxins on their tails generates dangerous injuries and an intense nociceptive response in the handler (Haddad Jr. et al. 2004; Silva et al. 2015; Kimura et al. 2018; Silva et al. 2020).

Synthetic chemical anesthetic substances, such as MS-222 (tricaine methanesulfonate), ketamine, propofol, tiletamine and zolazepan have been assessed in marine and freshwater elasmobranch species (Mylniczenko et al. 2014; Lécu et al. 2017). For instance, in the freshwater stingray Potamotrygon motoro, oral administration of $50 \mathrm{mg} \mathrm{kg}^{-1}$ ketamine promoted only a sedative state, not reaching deep anesthesia (Raines and Clancy 2009).

Anesthetics are also used in fish during management procedures to reduce the secondary responses to stress (Marshall et al. 2012; Husen and Sharma 2014). Cortisol is the main parameter for assessing the stress response in teleost fish (Wendelaar Bonga 1997; Balasch and Tort 2019), while in elasmobranchs, this role is attributed to 1-a hydroxycorticosterone, a steroid hormone produced by interrenal cells (Idler and Truscott 1966; Anderson 2012; Lambert et al. 2018). Although Ruiz-Jarabo et al. (2019) recently revealed the glucocorticoid action of this hormone in an elasmobranch species (Scyliorhinus canicula) submitted to air exposure, the measurement of this hormone is still complicated (Wheaton et al. 2018), 
limiting its use in routine stress monitoring practices. Thus, other parameters like corticosterone and plasma metabolite levels like glucose are also used as physiological indicators of stress in this animal group (Brinn et al. 2012; Marshall et al. 2012; Ariotti at al. 2021).

In recent years, the search for anesthetics of natural origin as an alternative to replace chemical anesthetics has intensified, for both teleost (Hoseini et al. 2019; Souza et al. 2019a) and marine elasmobranch species (Silbernagel and Yochem 2016; Takatsuka et al. 2019). Eugenol is the major component (80-90\%) of the oil initially extracted from the clove Syzygium aromaticum, a plant species that originated in Indonesia and spread worldwide due to its plentiful medicinal and pharmacological properties (Lorenzini and Matos 2008; Ascenção and Filho 2013). Considering its natural source, low cost and anesthetic efficiency, eugenol has become one of the main options for bath anesthesia and sedation in teleost fish (Hoseini et al. 2019; Souza et al. 2019a). In anesthetic trials using eugenol for the marine ray Zapteryx brevirostris, safe induction and good recovery times were observed (Takatsuka et al. 2019). On the other hand, the exposure of marine sharks, i.e. Triakis semifasciata and Mustelus californicus, to AQUI-S $20 \mathrm{E} \circledast$, which contains $10 \%$ pure eugenol in its formulation, resulted in longer induction and recovery times in these animals compared to a teleost species investigated in the same studies (Silbernagel and Yochem 2016; Lécu et al. 2017). These previous findings indicate that the observed responses to the same anesthetic type may differ in the distinct elasmobranch species investigated so far.

The essential oil of Lippia alba (EOLA) comes from an aromatic shrub belonging to the Verbenaceae Family. It is a tropical plant species found throughout South and Central America and Africa, and with different chemotypes (Hennebelle et al. 2008). The use of increasing concentrations of EOLA linalool chemotype proportionally decreased the induction time to anesthesia in the seahorse Hippocampus reidi (Cunha 2011), the Nile tilapia Oreochromis niloticus (Hohlenwerger et al. 2016), and the silver catfish Rhamdia quelen (Cunha et al. 2010; Toni et al. 2014). However, to date, there are no studies demonstrating the anesthetic efficiency of EOLA in elasmobranchs. Although there are a great number of studies involving anesthesia in teleost fishes, most of them looks to the establishment of induction and recovery times, not taking in consideration the possible adverse effects and the consequent physiological responses evoked in these animals to restore homeostasis.

The cururu stingray Potamotrygon wallacei (Carvalho et al. 2016) is the smallest species of Amazonian freshwater stingray known so far (maximum disc width of $310 \mathrm{~mm}$ ) and endemic to the middle Negro River basin. This species is resistant to acidic waters with low conductivity and dissolved oxygen levels (Oliveira et al. 2017; Carvalho et al. 2016), and its rusticity, small size, and a high level of individual polychromatism are additional attributes that make this species the second most exported potamotrygonid species in the Amazon region to the international ornamental fish trade (Carvalho et al. 2016).

Thus, this study aimed to assess the potential of eugenol and EOLA in providing suitable anesthetic induction and recovery times, as well as their consequent effects on the respiratory physiology, gill 
morphological features, and survival of $P$. wallacei, immediately after anesthesia, and after 48 hours of recovery to both anesthetics.

\section{Material And Methods}

\subsection{Capture and acclimatization of animals}

Juveniles of $P$. wallacei (disc width between 120 and 140 mm; Araújo 1998) were obtained by professional fishermen between December 2017 and February 2018 through night catches in the Igarapé Daraquá $\left(0^{\circ} 30^{\prime} 23.4504^{\prime \prime} \mathrm{S}, 63^{\circ} 12^{\prime} 51.3^{\prime \prime} \mathrm{W}\right)$, located in the Mariuá Archipelago, near the Municipality of Barcelos, Amazonas, Brazil. Immediately after capture, the stingrays were individually kept in plastic monoblocs containing fresh water from the capture site and taken to the basecamp, where they were temporarily stored in $1 \mathrm{~m}^{3}$ net tanks ( $n=6-8$ per tank) fixed in the river, containing sand at the bottom for greater animal comfort. Subsequently, the stingrays were transported to the city of Barcelos, then transferred to different monoblocs containing 10 liters of fresh and oxygenated water from the Rio Negro and transported by boat ( 24 hours) to the city of Manaus. From there, they were transported to the Laboratory of Experimental Physiology and Behavior of Aquatic Animals (LEFCAQ), at the Federal University of Amazonas (UFAM) and acclimated for 15 days (Ariotti et al. 2021) in plastic pools (400 L) provided with constant aeration and water renewal from an artesian well. During this period, the water quality parameters in the acclimatization polls were monitored by using an Orion Five Star multiparametric device (Thermo Scientific Inc., USA), and the following values (mean \pm SD) were obtained: electrical conductivity $=8.23 \pm 0.2 \mu \mathrm{sm}^{-1}$, dissolved oxygen $=5.03 \pm 0.7 \mathrm{mg} \mathrm{L}^{-1}, \mathrm{pH}=5.20 \pm$ 0.4 units, and temperature $=26.01 \pm 0.5^{\circ} \mathrm{C}$. The stingrays were fed daily with $2-3 \%$ of body weight with live earthworms and shrimps, and small pieces of fresh fish. Unconsumed food and fecal residues were removed by siphoning daily, and fresh water was restored from the same source.

This work followed all the legal requirements for capture and manipulation of free-living cururu stingrays, which include a permanent license for collection of zoological material, registered (SISBIO No. 18285-1) at the Chico Mendes Institute for Conservation and Biodiversity (ICMBio), linked to the Ministry of the Environment, and the approval of the Ethics Committee on the Use of Animals in Research of the Federal University of Amazonas (registry number \#002/2017-CEUA/UFAM) that was developed in accordance with the rules of ethical principles for animal experimentation approved by the Brazilian Council for the Control of Animal Experimentation (CONCEA). The use of juvenile specimens was defined based on ICMbio regulations (IN N . 204/2008) that determine neonates and this size class for commercialization at the international ornamental fish trade.

\subsection{Obtaining eugenol and Lippia alba essential oils}

The eugenol used in the tests (99-100\%; Biodynamics, Ibiporã, PR, Brazil) was acquired from the local market. The essential oil of $L$. alba (EOLA) was obtained from leaves from fresh plants cultivated at the campus Frederico Westphalen from Federal University of Santa Maria (UFSM), Rio Grande do Sul, Brazil, 
by hydrodistillation in Clevenger apparatus for 3 hours, as recommended by the European Pharmacopoeia (2007). Linalool was the major chemotype component (Souza et al. 2019b). Aliquots of EOLA $(20 \mathrm{~mL})$ were stored in separate amber glass jars, sealed, and stored at $-4^{\circ} \mathrm{C}$ until the experiments were initiated.

\subsection{Pilot studies}

Considering the lack of data in the literature on the use of eugenol in freshwater stingrays, pilot studies were conducted to refine the range of variation of acceptable eugenol levels for $P$. wallacei. In these experiments, juveniles ( $\mathrm{n}=3$ for each concentration) with a disc width of $110.7 \pm 36.5 \mathrm{~mm}$ and weight of $109.5 \pm 30.7 \mathrm{~g}$ were exposed to increasing concentrations of eugenol, i.e., 50, 75, 100, 125, 150, 200 and $300 \mu \mathrm{L} \mathrm{L}^{-1}$, established from previous studies conducted with marine stingray and shark species (Stamper 2004; Grusha 2005; Takatsuka et al. 2019).

Similar procedures were applied with the use of EOLA, in which juvenile stingrays ( $n=3$ for each concentration) were exposed to increasing concentrations of $50,100,150,200,300$ and $500 \mu \mathrm{L} \mathrm{L}^{-1}$. Since there are no reports of studies addressing the use of EOLA as an anesthetic substance for any elasmobranch species, either marine or freshwater, the range of previously tested concentrations was defined considering the data observed for different teleost species (Cunha et al. 2010; 2011; Toni et al. 2014; Hohlenwerger et al. 2016). Due to the weak solubility of eugenol and EOLA in water, these substances were diluted in ethanol $(1: 10, \mathrm{v} / \mathrm{v})$ immediately before use and kept at room temperature.

To perform these experiments, stingrays were individually transferred from the acclimatization pools to the experimental aquariums $(40 \mathrm{~L})$ containing the different concentrations of both anesthetics. The stingrays were fasted $24 \mathrm{~h}$ before the start of the experiments to avoid regurgitation and possible branchial obstruction. The water used in the experimental aquariums was the same as used in the acclimatization pools, and was fully renewed at the end of each tested concentration.

The different stages of anesthesia proposed for marine elasmobranch species (Stamper 2004) were applied to the cururu stingray for the definition of the anesthetic plan (Table 1). During anesthetic exposure, the ventilatory (spiracular) frequency, swimming capacity, and tonus and reflex muscle activity of each animal were evaluated and recorded in a minute-by-minute interval. When the animal stopped moving and showed a marked reduction of spiracular frequency, it underwent stimulation by means of slight touching with a glass stick in the anterior and posterior regions of the disc edge. When it no longer responded to stimuli with the glass stick, and to make sure that it was in a stage of deep anesthesia, the animal had its body gently turned to the supine position (belly upwards) with the aid of the glass stick [Fig. SI-1 (Supplementary information)]. In those cases, the confirmation that the stingray had reached a plane of deep anesthesia (stage III, Table 1) was assumed from the observed instant it was unable to reverse to the normal body position. This was considered a fundamental procedure, since the stingray routinely remains at the bottom of the aquarium and the loss of balance in the water column often used in teleosts to define the anesthetic event (Sneddon 2012; Zahl et al. 2012) is not applicable to these 
animals and may even induce errors during the determination of the real anesthetic times of induction and recovery.

Table 1

Anesthesia stages proposed for Potamotrygon wallacei.

Adapted from Stamper (2004).

\begin{tabular}{|c|c|c|}
\hline Stages & Description & Behavioral Responses \\
\hline 0 & Normal & $\begin{array}{l}\text { Active swimming, reactive to external stimuli, normal spiracular rhythm; } \\
\text { normal muscle tone. }\end{array}$ \\
\hline \multirow[t]{2}{*}{ I } & $\begin{array}{l}\text { Slight } \\
\text { sedation }\end{array}$ & $\begin{array}{l}\text { Rays still swims; slight loss of reactivity to visual and tactile stimuli; normal } \\
\text { spiracular rhythm and muscle tone. }\end{array}$ \\
\hline & $\begin{array}{l}\text { Deep } \\
\text { sedation }\end{array}$ & $\begin{array}{l}\text { Cessation of voluntary swimming, total loss of reactivity to visual and tactile } \\
\text { stimulation, slight decrease in spiracular rhythm and muscle tone. }\end{array}$ \\
\hline \multirow[t]{2}{*}{ II } & $\begin{array}{l}\text { Slight } \\
\text { narcosis }\end{array}$ & $\begin{array}{l}\text { Excitation phase, erratic and uncontrolled swimming, partial loss of muscle } \\
\text { tone; irregular spiracular rhythm; reactive only to strong stimulus, responds } \\
\text { to position changes. }\end{array}$ \\
\hline & $\begin{array}{l}\text { Deep } \\
\text { narcosis }\end{array}$ & $\begin{array}{l}\text { Ray ceases to respond to changes in position, decreased spiracular rhythm } \\
\text { and muscle tone, reactive to strong stimulus. }\end{array}$ \\
\hline \multirow[t]{2}{*}{ III } & $\begin{array}{l}\text { Slight } \\
\text { anesthesia }\end{array}$ & $\begin{array}{l}\text { Total loss of swimming balance and muscle tone; even greater decrease in } \\
\text { spiracular rhythm; suitable for minor surgical procedures. }\end{array}$ \\
\hline & $\begin{array}{l}\text { Deep } \\
\text { anesthesia }\end{array}$ & $\begin{array}{l}\text { Total absence of reaction, even to strong stimulus; very low spiracular } \\
\text { rhythm; total loss of all reflexes. }\end{array}$ \\
\hline IV & $\begin{array}{l}\text { Medullar } \\
\text { collapse }\end{array}$ & Respiratory failure and eventual death. \\
\hline
\end{tabular}

Immediately after reaching the level of deep anesthesia and recording the time, the stingray was transferred to another aquarium with the same size and volume containing anesthetic-free water. During the recovery phase, the same physiological and behavioral parameters of induction were recorded. Recovery was considered complete when the animal showed stable and guided swimming, avoiding the walls of the aquarium. For this evaluation step, the five recovery stages established by Grusha (2005) for the marine stingray Rhinoptera bonasus were adopted to juveniles of $P$. wallacei (Table 2). 
Table 2

Stages of anesthetic recovery proposed for Potamotrygon wallacei.

Adapted from Grusha (2005).

\begin{tabular}{|ll|}
\hline Recovery Stages & Behavioral Responses \\
\hline I & Increased respiratory effort, measured by increased spiracular rhythm. \\
\hline III & Muscle movement and partial return of swimming ability. \\
\hline IV & Slow swimming \\
\hline V & Muscle movement and partial return of swimming capacity. \\
2.4. Anesthesia protocols
\end{tabular}

The anesthetic concentrations of $75,100,125$ and $150 \mu \mathrm{LL}^{-1}$, and 150, 175, 200 and $225 \mu \mathrm{L} \mathrm{L}^{-1}$ were defined for eugenol and EOLA, respectively, based on the results obtained in the pilot studies. In each anesthetic concentration evaluated for both anesthetics, twelve $(n=12)$ stingrays were used and transferred individually from the acclimatization polls to the experimental aquariums with the different tested anesthetics concentrations. Six stingrays $(n=6)$ were sampled at each concentration shortly after reaching the deep anesthesia, and the other six animals ( $n=6$ each concentration) were assessed $48 \mathrm{~h}$ after the recovery from anesthesia.

The sampling after $48 \mathrm{~h}$ aimed to evaluate the physiological responses of the animals, in addition to monitoring the resumption of normal food intake and survival after exposure to the concentrations of both anesthetics. For this, in each procedure, a moistened cotton towel was used to avoid skin dryness, and each stingray was gently placed in dorsal decubitus and punctured in the branchial vessel, with $3 \mathrm{~mL}$ syringes containing 10\% EDTA used to obtain blood samples. Then, biometric measures (weight, length, and disc width) were performed, and the stingrays were immediately euthanized by sectioning the spinal cord, for necropsy and removal of gills for a histological evaluation.

During induction, the following water quality parameters (mean $\pm S D$ ) were observed: electrical conductivity $=9.2 \pm 0.2 \mu \mathrm{S} \mathrm{cm}^{-1}$, dissolved oxygen $=5.7 \pm 0.2 \mathrm{mg} \mathrm{L}^{-1}$, temperature $=26.9 \pm 0.1^{\circ} \mathrm{C}$, and $\mathrm{pH}$ $=5.5 \pm 0.1$ units. During the phase of anesthetic recovery, the following values were recorded: electrical conductivity $=9.9 \pm 0.2 \mu \mathrm{S} \mathrm{cm}^{-1}$, dissolved oxygen $=5.5 \pm 0.3 \mathrm{mg} \mathrm{L}^{-1}$, temperature $=26.7 \pm 0.1^{\circ} \mathrm{C}$, and $\mathrm{pH}$ $=5.5 \pm 0.2$ units. There were no significant differences $(p>0.05)$ between the water quality parameters measured during anesthetic induction, when compared to the recovery phase.

\subsection{Spiracular frequency}

The ventilatory responses of $P$. wallacei juveniles exposed to both anesthetics were estimated through the frequency of spiracular movements (SF; beats $\mathrm{min}^{-1}$ ), and measured by direct counting of the number of spiracle movements for 1 min at 60 minute intervals, according to Graham et al. (1990). Twelve stingrays 
$(n=12)$ had their SF assessed in the anesthetic-exposed treatments of eugenol and EOLA, and six $(n=6)$ in the basal (not exposed and not handled) group. Two consecutive counts of spiracular movements were performed in the same animal at each time interval for a greater accuracy, and the average was considered for quantification of ventilatory rate.

\subsection{Blood parameters}

The hematocrit $(\mathrm{Ht}, \%)$ was determined in whole blood samples by the microhematocrit method (Goldenfarb et al. 1971). After that, plasma was separated by centrifugation (3000 rpm for 3 minutes), placed in cryogenic vials, and immediately stored in an ultrafreezer at $-80^{\circ} \mathrm{C}$ (Sanyo Corp., New York, USA) until laboratory analysis. Plasma glucose $\left(\mathrm{mmol} \mathrm{L}^{-1}\right)$, total proteins $\left(\mathrm{g} \mathrm{L}^{-1}\right)$, triglycerides $\left(\mathrm{mmol} \mathrm{L}^{-1}\right)$, total cholesterol $\left(\mathrm{mmol} \mathrm{L}^{-1}\right)$, urea $\left(\mathrm{mmol} \mathrm{L}^{-1}\right)$ and lactate $\left(\mathrm{mmol} \mathrm{L}^{-1}\right)$ levels were determined using an automated reader device (Chemwell, Awareness Technology Inc., Miami, USA), using specific enzymaticcolorimetric kits (Labtest Diagnóstica S.A., Lagoa Santa, MG, Brazil) for each plasma constituent.

\subsection{Gill histology}

The gills of each individual stingray were fixed in $10 \%$ buffered formaldehyde and part of the second branchial arch filaments (Duncan et al. 2010b, 2011) was separated and gradually dehydrated in alcohol series (70 to $100 \%)$, diaphanized with xylol, and embedded in paraffin at $60^{\circ} \mathrm{C}$. Then, $5 \mu \mathrm{m}$ sections were obtained using a Leica microtome (model RM 2125RT, Leica Microsystems, Wetzlar, Germany), stained with hematoxylin-eosin and assembled for further analysis and photographic documentation, using a Leica DM500 optical microscope with an integrated Leica ICC50 W camera (Leica Microsystems, Wetzlar, Germany). The observations made by Karan et al. (1998) for common carp exposed to copper sulfate were followed to identify and classify histopathological changes in the gills of $P$. wallacei.

\subsection{Statistical analysis}

All data were previously checked for homoscedasticity and normality by the Levene and Shapiro-Wilk tests, respectively. Data regarding the spiracular frequency and water quality parameters were submitted to one-way ANOVA and Tukey posteriori test, or Kruskal-Wallis one-way ANOVA on ranks followed by Dunn's posteriori test for non-homoscedastic data. Hematocrit and plasma metabolite values obtained from stingrays just after the onset of anesthesia for both eugenol and EOLA were compared to those after 48 hours of recovery through a Student's t-test. Tests were performed with the software SigmaPlot version 11.0 and statistical significance was accepted at $p<0.05$.

\section{Results}

\subsection{Anesthesia with eugenol}

During the pilot studies, stingrays exposed to $50 \mu \mathrm{L} \mathrm{L}^{-1}$ of eugenol took more than 10 minutes to anesthetize and more than 20 minutes to recover. A 50\% mortality rate was observed during the recovery phase of stingrays $(n=6)$ exposed to this concentration. In stingrays exposed to $175 \mu \mathrm{L} \mathrm{L}^{-1}$ of eugenol, 
remarkable burns were observed at the edge of the disc [Fig. SI-2 (Supplementary information)], while at $200 \mu \mathrm{L} \mathrm{L}^{-1}$ the animals ceased spiracular movements and $50 \%$ died due to pronounced respiratory depression.

Most stingrays showed hyperactive behavior at the first contact with the four evaluated concentrations of eugenol $\left(75,100,125\right.$ and $\left.150 \mu L^{-1}\right)$. Initially, there was an increase in the rate of spiracular movements (0-1 min), followed by eye and spiracle closure, increased movement of fins and sudden swimming movements. Moments after (1-2 min), the stingrays began to calm down, reaching Stage I (sedation). Soon after (2-4 min), they reached Stage II (excitation), again showing sudden swimming movements and irregular breathing, but at greater intensity. After this period, stingrays again decreased their fin movements and exhibited increased respiratory effort, with increased amplitude of spiracular opening movements. The marked depression of the ventilatory frequency, associated with the total absence of disc movements and reflex activity (when stimulated with the glass stick), demonstrated that the animal had reached the Stage III (anesthesia), on average between 4 and 5.27 minutes after the first contact with eugenol (Table 3).

Table 3

Time required (in minutes; mean \pm SEM) to reach deep anesthesia and recovery in juveniles of Potamotrygon wallacei $(\mathrm{n}=12)$ exposed to different concentrations of eugenol and EOLA. Different letters on the same line indicate significant difference between the tested concentrations $(p<0.05)$.

\begin{tabular}{|c|c|c|c|c|}
\hline Treatments & Concentrations & & & \\
\hline Eugenol & $75 \mu L^{-1}$ & $100 \mu L^{-1}$ & $125 \mu \mathrm{L} \mathrm{L}^{-1}$ & $150 \mu L^{-1}$ \\
\hline Induction & $5.27 \pm 0.97 a$ & $4.00 \pm 0.79 b$ & $4.74 \pm 0.81 \mathrm{ab}$ & $4.40 \pm 0.76 a b$ \\
\hline Recovery & $16.38 \pm 4.99 a$ & $15.33 \pm 2.59 a$ & $17.69 \pm 3.08 a$ & $16.88 \pm 5.27 a$ \\
\hline Lippia alba & $150 \mu L^{-1}$ & $175 \mu L^{-1}$ & $200 \mu L^{-1}$ & $225 \mu L^{-1}$ \\
\hline Induction & $12.43 \pm 4.62 a$ & $7.15 \pm 1.15 b$ & $6.83 \pm 1.54 b$ & $4.79 \pm 1.09 b$ \\
\hline Recovery & $13.30 \pm 5.00 a$ & $9.71 \pm 2.77 a b$ & $8.78 \pm 2.15 b$ & $12.87 \pm 4.46 a b$ \\
\hline
\end{tabular}

The first contact reactions were more intense at 125 and $150 \mu \mathrm{L} \mathrm{L}^{-1}$. Stage I (sedation) was fast or almost imperceptible, followed by Stage II with hyperexcitation, uncontrolled swimming, then rapid and deep ventilatory depression, culminating in some cases with the cessation of spiracular movements. These animals presented marked hyperemia in the region of the mouth, belly, and genitalia. The death of one stingray was recorded during the recovery phase of anesthesia at $100 \mu \mathrm{L} \mathrm{L}^{-1}$, and two others during exposure to $150 \mu \mathrm{L} \mathrm{L}^{-1}$ of eugenol. No significant differences were found in the induction times between the concentrations of 100,125 and $150 \mu \mathrm{L} \mathrm{L}^{-1}$ of eugenol, except that $75 \mu \mathrm{L} \mathrm{L}^{-1}$ required more time to induce anesthesia. The recovery time from the anesthesia was, on average, between 15 and $17.6 \mathrm{~min}$, with no significant differences between all tested eugenol concentrations. 


\subsection{Anesthesia with Lippia alba essential oil (EOLA)}

During the pilot studies, the stingrays exposed to 50 and $100 \mu \mathrm{L} \mathrm{L}^{-1}$ EOLA $(n=3)$ did not reach anesthesia after 10 minutes of exposure. At $300 \mu \mathrm{L} \mathrm{L}^{-1}$ both tested animals $(n=2)$ showed neurological sequelae after exposure (escape from offered food and irregular swimming movements 12 hours after recovery), while exposure to $500 \mu \mathrm{L} \mathrm{L}^{-1}$ led to the death of exposed stingrays $(n=2)$ due to profound ventilatory failure during the induction phase.

The stingrays took, on average, between 4 and $12.4 \mathrm{~min}$ to reach the different anesthetic stages (Table 3 ) when exposed to $150,175,200$ and $225 \mu \mathrm{L} \mathrm{L}^{-1}$, and presented a mild reaction at the first contact with the anesthetic, with slight excitatory phase (Stage II) and no evidence of ventilatory failure or mortality in any of the tested anesthetic concentrations.

The mean recovery times for EOLA were between 8 and $13.3 \mathrm{~min}$ for all tested concentrations. Stingrays anesthetized with $200 \mu \mathrm{L} \mathrm{L}^{-1}$ showed significantly faster recovery than those anesthetized with $150 \mu \mathrm{L}$ $\mathrm{L}^{-1}(\mathrm{p}<0.05)$ (Table 3).

\subsection{Spiracular frequency}

Under basal conditions, the SF of the stingrays maintained in the acclimation pools ranged from 36 to 60 beats $\mathrm{min}^{-1}$. Significantly higher SF values $(p<0.05)$ were observed in the groups of stingrays submitted to different concentrations of eugenol during the onset of anesthesia when compared to basal group, with exception of those exposed to $125 \mathrm{LL} \mathrm{L}^{-1}$ (Fig. 1A-D). No significant differences were observed between stingrays assessed in the deep anesthesia and recovery phases at the different concentrations of eugenol ( $p>0.05)$, even compared to the basal group (Fig. 1).

Stingrays evaluated at the onset of anesthesia with EOLA only showed significantly higher $S F(p<0.05)$ than the basal group at $150 \mu \mathrm{L} \mathrm{L}^{-1}$. On the other hand, significantly lower values of SF were observed during the deep anesthesia stage compared to the onset of anesthesia in all the tested concentrations, except for $225 \mu \mathrm{L} \mathrm{L}^{-1}$. Also, stingrays exposed to $150 \mu \mathrm{L} \mathrm{L}^{-1}$ and $225 \mu \mathrm{L} \mathrm{L}-1$ EOLA presented higher SF values $(p<0.05)$ in the recovery stage compared to the deep anesthesia (Fig. 2A-D).

During anesthetic induction at the tested concentrations with eugenol, the SF remained in a higher/elevated range, when compared to those recorded for EOLA-anesthetized animals. The SF timeresponse was not coincident to the tested concentrations of eugenol at the anesthetic induction, with a sudden/rapid decrease in the last minutes, and a fast return of stable SF values to $30-50$ beats $\mathrm{min}^{-1}$ during the recovery phase (Fig. 1E). On the other hand, the decrease of SF in the stingrays exposed to EOLA was gradual with a regular distribution throughout the induction phase and proportional to the tested concentration, i.e., higher concentrations induced a more pronounced decrease in SF and a longer return time to recovery. Also, as the stingrays recovered, the SF gradually returned to values of 30 to 50 
beats $\min ^{-1}$, and in all tested concentrations the range of variation between animals was lower than in those anesthetized with eugenol (Fig. 2E).

\subsection{Blood parameters}

No significant differences were found $(p>0.05)$ for hematocrit and plasma metabolite levels assessed in stingrays exposed to all concentrations of eugenol between the time of deep anesthesia and after 48 hours of recovery (Table 4$)$. Similarly, these parameters did not change $(p>0.05)$ in stingrays exposed to all concentrations of EOLA when the group sampled just after the deep anesthesia was compared with those sampled after 48 hours of recovery (Table 5).

Table 4

Blood parameters obtained for juveniles of cururu stingray (Potamotrygon wallacei) shortly after reaching deep anesthesia $(n=6)$ and after 48 hours of recovery from anesthesia $(n=6)$ with different concentrations of eugenol $\left(\mu L^{-1}\right)$. No significant differences were observed $(p>0.05)$ for any parameter in all tested concentrations of eugenol when stingrays submitted to anesthesia were compared to those after 48 hours of recovery.

\begin{tabular}{|c|c|c|c|c|c|c|c|c|}
\hline \multirow[t]{2}{*}{ Parameter } & \multicolumn{4}{|c|}{$\begin{array}{l}\text { Shortly after reaching deep } \\
\text { anesthesia }\end{array}$} & \multicolumn{4}{|c|}{ After $48 \mathrm{~h}$ recovery } \\
\hline & 75 & 100 & 125 & 150 & 75 & 100 & 125 & 150 \\
\hline Hematocrit (\%) & $\begin{array}{l}19.08 \\
\pm 1.7\end{array}$ & $\begin{array}{l}18.33 \\
\pm 2.8\end{array}$ & $\begin{array}{l}19.94 \\
\pm 2.4\end{array}$ & $\begin{array}{l}20.53 \\
\pm 2.5\end{array}$ & $\begin{array}{l}19.25 \\
\pm 2.6\end{array}$ & $\begin{array}{l}18.58 \\
\pm 1.2\end{array}$ & $\begin{array}{l}19.75 \\
\pm 1.9\end{array}$ & $\begin{array}{l}20.83 \\
\pm 2.1\end{array}$ \\
\hline $\begin{array}{l}\text { Glucose (mmol } \\
\left.\mathrm{L}^{-1}\right)\end{array}$ & $\begin{array}{l}1.35 \\
\pm 0.20\end{array}$ & $\begin{array}{l}1.26 \\
\pm 0.04\end{array}$ & $\begin{array}{l}1.21 \\
\pm 0.10\end{array}$ & $\begin{array}{l}1.07 \\
\pm 0.10\end{array}$ & $\begin{array}{l}1.09 \\
\pm 0.13\end{array}$ & $\begin{array}{l}1.17 \\
\pm 0.16\end{array}$ & $\begin{array}{l}1.04 \pm \\
0.11\end{array}$ & $\begin{array}{l}0.98 \pm \\
0.06\end{array}$ \\
\hline $\begin{array}{l}\text { Cholesterol } \\
\left(\mathrm{mmol} \mathrm{L}^{-1}\right)\end{array}$ & $\begin{array}{l}2.09 \\
\pm 0.42\end{array}$ & $\begin{array}{l}2.04 \\
\pm 0.23\end{array}$ & $\begin{array}{l}1.57 \\
\pm 0.28\end{array}$ & $\begin{array}{l}1.56 \\
\pm 0.23\end{array}$ & $\begin{array}{l}2.24 \\
\pm 0.37\end{array}$ & $\begin{array}{l}1.78 \\
\pm 0.21\end{array}$ & $\begin{array}{l}1.55 \pm \\
0.26\end{array}$ & $\begin{array}{l}2.09 \pm \\
0.16\end{array}$ \\
\hline $\begin{array}{l}\text { Triglycerides } \\
\left(\mathrm{mmol} \mathrm{L}^{-1}\right)\end{array}$ & $\begin{array}{l}0.71 \\
\pm 0.15\end{array}$ & $\begin{array}{l}0.81 \\
\pm 0.12\end{array}$ & $\begin{array}{l}0.45 \\
\pm 0.05\end{array}$ & $\begin{array}{l}0.99 \\
\pm 0.10\end{array}$ & $\begin{array}{l}0.79 \\
\pm 0.22\end{array}$ & $\begin{array}{l}1.00 \\
\pm 0.07\end{array}$ & $\begin{array}{l}0.48 \pm \\
0.11\end{array}$ & $\begin{array}{l}0.90 \pm \\
0.12\end{array}$ \\
\hline $\begin{array}{l}\text { Total proteins } \\
\left(\mathrm{g} \cdot \mathrm{L}^{-1}\right)\end{array}$ & $\begin{array}{l}7.60 \\
\pm 1.13\end{array}$ & $\begin{array}{l}7.58 \\
\pm 0.89\end{array}$ & $\begin{array}{l}9.85 \\
\pm 0.40\end{array}$ & $\begin{array}{l}7.89 \\
\pm 0.94\end{array}$ & $\begin{array}{l}8.20 \\
\pm 1.01\end{array}$ & $\begin{array}{l}7.60 \\
\pm 1.33\end{array}$ & $\begin{array}{l}10.92 \\
\pm 0.88\end{array}$ & $\begin{array}{l}10.08 \\
\pm 1.41\end{array}$ \\
\hline $\begin{array}{l}\text { Urea (mmol L- } \\
\left.{ }_{1}^{-}\right)\end{array}$ & $\begin{array}{l}1.81 \\
\pm 0.35\end{array}$ & $\begin{array}{l}2.09 \\
\pm 0.18\end{array}$ & $\begin{array}{l}1.70 \\
\pm 0.13\end{array}$ & $\begin{array}{l}1.74 \\
\pm 0.19\end{array}$ & $\begin{array}{l}1.87 \\
\pm 0.19\end{array}$ & $\begin{array}{l}1.85 \\
\pm 0.21\end{array}$ & $\begin{array}{l}1.76 \pm \\
0.28\end{array}$ & $\begin{array}{l}1.88 \pm \\
0.25\end{array}$ \\
\hline $\begin{array}{l}\text { Lactate (mmol } \\
\mathrm{L}^{-1} \text { ) }\end{array}$ & $\begin{array}{l}4.97 \\
\pm 0.22\end{array}$ & $\begin{array}{l}7.17 \\
\pm 1.10\end{array}$ & $\begin{array}{l}6.32 \\
\pm 1.00\end{array}$ & $\begin{array}{l}4.63 \\
\pm 0.59\end{array}$ & $\begin{array}{l}6.80 \\
\pm 1.20\end{array}$ & $\begin{array}{l}8.50 \\
\pm 2.02\end{array}$ & $\begin{array}{l}7.33 \pm \\
1.45\end{array}$ & $\begin{array}{l}5.52 \pm \\
0.56\end{array}$ \\
\hline
\end{tabular}


Table 5

Blood variables obtained for juveniles of cururu stingray (Potamotrygon wallacei) shortly after reaching deep anesthesia $(n=6)$ and after 48 hours of recovery from anesthesia $(n=6)$ with different concentrations of EOLA $\left(\mu L^{-1}\right)$. No significant differences were observed $(p>0.05)$ for any parameter in all tested concentrations of EOLA when stingrays submitted to anesthesia were compared to those after 48 hours of recovery.

\begin{tabular}{|c|c|c|c|c|c|c|c|c|}
\hline \multirow[t]{2}{*}{ parameter } & \multicolumn{3}{|c|}{$\begin{array}{l}\text { Shortly after reaching deep } \\
\text { anesthesia }\end{array}$} & \multicolumn{5}{|c|}{ After $48 \mathrm{~h}$ recovery } \\
\hline & 150 & 175 & 200 & 225 & 150 & 175 & 200 & 225 \\
\hline Hematocrit (\%) & $\begin{array}{l}19.97 \\
\pm 3.6\end{array}$ & $\begin{array}{l}20.08 \\
\pm 3.2\end{array}$ & $\begin{array}{l}15.22 \\
\pm 3.4\end{array}$ & $\begin{array}{l}19.52 \\
\pm 5.7\end{array}$ & $\begin{array}{l}18.20 \\
\pm 3.2\end{array}$ & $\begin{array}{l}23.42 \\
\pm 2.3\end{array}$ & $\begin{array}{l}17.25 \\
\pm 3.9\end{array}$ & $\begin{array}{l}18.19 \\
\pm 4.9\end{array}$ \\
\hline $\begin{array}{l}\text { Glucose (mmol } \\
\left.\mathrm{L}^{-1}\right)\end{array}$ & $\begin{array}{l}1.48 \\
\pm 0.28\end{array}$ & $\begin{array}{l}1.01 \\
\pm 0.08\end{array}$ & $\begin{array}{l}1.17 \\
\pm 0.17\end{array}$ & $\begin{array}{l}0.99 \\
\pm 0.13\end{array}$ & $\begin{array}{l}1.54 \pm \\
0.18\end{array}$ & $\begin{array}{l}1.10 \\
\pm 0.14\end{array}$ & $\begin{array}{l}1.07 \\
\pm 0.17\end{array}$ & $\begin{array}{l}1.11 \\
\pm 0.13\end{array}$ \\
\hline $\begin{array}{l}\text { Cholesterol } \\
\left(\mathrm{mmol} \mathrm{L}^{-1}\right)\end{array}$ & $\begin{array}{l}2.17 \\
\pm 0.38\end{array}$ & $\begin{array}{l}1.83 \\
\pm 0.19\end{array}$ & $\begin{array}{l}0.91 \\
\pm 0.10\end{array}$ & $\begin{array}{l}1.68 \\
\pm 0.26\end{array}$ & $\begin{array}{l}2.38 \pm \\
0.29\end{array}$ & $\begin{array}{l}1.61 \\
\pm 0.26\end{array}$ & $\begin{array}{l}0.87 \\
\pm 0.10\end{array}$ & $\begin{array}{l}1.72 \\
\pm 0.29\end{array}$ \\
\hline $\begin{array}{l}\text { Triglycerides } \\
\left(\mathrm{mmol} \mathrm{L}^{-1}\right)\end{array}$ & $\begin{array}{l}0.40 \\
\pm 0.10\end{array}$ & $\begin{array}{l}0.67 \\
\pm 0.13\end{array}$ & $\begin{array}{l}0.26 \\
\pm 0.04\end{array}$ & $\begin{array}{l}0.56 \\
\pm 0.11\end{array}$ & $\begin{array}{l}0.61 \pm \\
0.12\end{array}$ & $\begin{array}{l}0.66 \\
\pm 0.12\end{array}$ & $\begin{array}{l}0.23 \\
\pm 0.03\end{array}$ & $\begin{array}{l}0.52 \\
\pm 0.14\end{array}$ \\
\hline $\begin{array}{l}\text { Total proteins } \\
\left(\mathrm{g} . \mathrm{L}^{-1}\right)\end{array}$ & $\begin{array}{l}8.43 \\
\pm 1.32\end{array}$ & $\begin{array}{l}8.80 \\
\pm 1.02\end{array}$ & $\begin{array}{l}6.91 \\
\pm 0.88\end{array}$ & $\begin{array}{l}5.32 \\
\pm 1.14\end{array}$ & $\begin{array}{l}7.52 \pm \\
1.18\end{array}$ & $\begin{array}{l}9.34 \\
\pm 0.99\end{array}$ & $\begin{array}{l}6.74 \\
\pm 0.57\end{array}$ & $\begin{array}{l}4.75 \\
\pm 1.19\end{array}$ \\
\hline $\begin{array}{l}\text { Urea }\left(\mathrm{mmol} \mathrm{L}^{-}\right. \\
\left.{ }^{1}\right)\end{array}$ & $\begin{array}{l}1.61 \\
\pm 0.11\end{array}$ & $\begin{array}{l}1.87 \\
\pm 0.31\end{array}$ & $\begin{array}{l}2.13 \\
\pm 0.45\end{array}$ & $\begin{array}{l}2.46 \\
\pm 0.52\end{array}$ & $\begin{array}{l}1.46 \pm \\
0.116\end{array}$ & $\begin{array}{l}1.85 \\
\pm 0.29\end{array}$ & $\begin{array}{l}2.00 \\
\pm 0.29\end{array}$ & $\begin{array}{l}2.56 \\
\pm 0.69\end{array}$ \\
\hline $\begin{array}{l}\text { Lactate }(\mathrm{mmol} \\
\left.\mathrm{L}^{-1}\right)\end{array}$ & $\begin{array}{l}6.17 \\
\pm 0.99\end{array}$ & $\begin{array}{l}4.78 \\
\pm 0.60\end{array}$ & $\begin{array}{l}6.06 \\
\pm 1.25\end{array}$ & $\begin{array}{l}5.30 \\
\pm 1.02\end{array}$ & $\begin{array}{l}6.59 \pm \\
1.50\end{array}$ & $\begin{array}{l}5.97 \\
\pm 0.62\end{array}$ & $\begin{array}{l}7.07 \\
\pm 1.35\end{array}$ & $\begin{array}{l}6.31 \\
\pm 1.16\end{array}$ \\
\hline
\end{tabular}

\subsection{Gill histology}

No histopathological changes were observed in the gill primary and secondary lamellae in juveniles of $P$. wallacei exposed to anesthetic-free water. These structures have a simple pavement epithelium and mucous cells supported by cuboid pillar cells, and groups of ionocytes (chloride cells) at their base (Fig. 3). A qualitative description of gill lesions found in stingrays anesthetized with different concentrations of eugenol and EOLA is shown in Table 6. 
Table 6

Qualitative analysis of the histological alterations observed in the gills of juveniles of Potamotrygon wallacei exposed to different concentrations of eugenol and EOLA.

\begin{tabular}{|c|c|c|c|c|c|c|c|c|}
\hline \multirow[t]{2}{*}{ Histopathological alterations } & \multicolumn{8}{|c|}{ Eugenol (mg L-1) Lippia alba $(\mu \mathrm{l} \mathrm{L}-1)$} \\
\hline & 75 & 100 & 125 & 150 & 150 & 175 & 200 & 225 \\
\hline Lamellar epithelium hypertrophy & + & + & + & ++ & + & + & + & + \\
\hline Lamellar epithelium hyperplasia & + & + & + & ++ & + & ++ & + & + \\
\hline Hypertrophy of ionocytes & + & - & - & + & ++ & + & - & + \\
\hline Hyperplasia of ionocytes & + & ++ & - & + & ++ & ++ & - & + \\
\hline Lamellar fusion & - & - & - & - & - & + & - & + \\
\hline Capillary dilation & + & - & - & + & + & + & + & + \\
\hline Epithelial detachment & - & - & - & + & - & - & - & - \\
\hline Epithelial rupture (hemorrhage) & - & - & + & - & - & - & - & - \\
\hline Presence of melanomacrophages & - & + & - & - & - & + & - & - \\
\hline Lamellar aneurysm & ++ & + & + & + & + & + & + & - \\
\hline Apoptosis of ionocytes cells & + & + & ++ & + & - & - & - & + \\
\hline Necrosis & - & + & ++ & ++ & - & - & - & - \\
\hline
\end{tabular}

Histopathological changes in the gills of the stingrays anesthetized with eugenol, such as hyperplasia and hypertrophy of epithelial cells and ionocytes (Fig. 4A), were reasonably frequent. In contrast, aneurysms in various sizes were accompanied by irreversible damage to lamellar architecture, such as apoptosis of ionocytes, filament epithelial detachment, and rupture of the epithelium (Fig. 4B-C-D) (Table 6). On the other hand, stingrays anesthetized with EOLA had a higher frequency of morphological alterations of the primary response, such as hyperplasia and hypertrophy of epithelial cells and ionocytes (Fig. 5A-B). Vascular alterations, such as capillary dilation and lamellar aneurysms, were observed in stingrays anesthetized with 150 to $200 \mu \mathrm{L} \mathrm{L}^{-1}$ (Fig. 5C). However, irreversible damage such as apoptosis of ionocytes was only observed in the group anesthetized with $225 \mathrm{LL} \mathrm{L}^{-1}$ (Table 6). Melanomacrophages were observed in the central blood vessel of the primary gill lamellae of stingrays anesthetized with 100 $\mu \mathrm{L} \mathrm{L}^{-1}$ of eugenol and $175 \mu \mathrm{L} \mathrm{L}-1$ of EOLA (Fig. 5D).

\section{Discussion}

The present study examined the potential use of eugenol and EOLA as anesthetic substances for application in juveniles of an Amazonian freshwater stingray species, Potamotrygon wallacei. To date, the use of both anesthetics is unprecedented for representatives of Potamotrygonidae family, and only a 
few investigations have assessed the effects of anesthetic substances obtained from herbal products on blood and plasma biochemistry (Frick at al. 2009); no studies have focused on use of EOLA in any elasmobranch fish. This also applies for the evaluation of potential histological alterations on the gills of these fish when they are in contact with these substances in the water. This limitation is, in part, due to complicated logistics in acclimatization and handling procedures to keep elasmobranchs in captivity, which makes the collection of physiological data after anesthesia a non-trivial task.

The similarity of the physical-chemical characteristics of the water observed during the acclimatization of the stingrays, as well as in the induction and recovery times in the experimental aquariums, are in line with the amplitude of these parameters documented in the areas of natural occurrence of the cururu stingray (Oliveira et al. 2017). This indicates that the behavioral (swimming capacity and reflex activity) and physiological responses (SF and blood parameters), as well as the histological changes observed in the gills of $P$. wallacei during anesthesia and recovery are attributed only to the effects of tested anesthetics, and not due to changes in the water quality used in the experiments.

As well as in teleosts, depression of ventilatory frequency and cardiac rate are expected responses in elasmobranch species under anesthesia (Hove and Moss 1997). For instance, a transitory decrease in ventilatory frequency (measured trough spiracular opening and closing movements) in the freshwater stingray $P$. motoro was observed after oral administration of $50 \mathrm{mg} \mathrm{kg}^{-1}$ of ketamine (Raines and Clancy 2009). Conversely, in the spotted bamboo shark (Chiloscyllium plagiosum), the intravenous administration of propofol $\left(2.5 \mathrm{mg} \mathrm{kg}^{-1}\right)$ resulted in stable respiratory and heart rates during anesthesia (Miller et al. 2005). These results indicate that cardiorespiratory responses may diverge in different species and according to the dosage and anesthetic type. In our study, the SF values obtained for the basal group of juveniles of $P$. wallacei before exposure to eugenol and EOLA are in line with those recorded for the same species (Pastório 2014) under normoxic conditions (40 to 60 beats $\mathrm{min}^{-1}$ ). On the other hand, it was observed that the first contact with eugenol resulted in a hyperactivity response, which was reflected in the maintenance of a high SF $\left(>60\right.$ beats $\left.\mathrm{min}^{-1}\right)$ during the onset of the induction phase in almost all tested concentrations. This pattern, associated with an excessively long excitatory phase (Stage II), may have resulted in stress and physical exhaustion, making the anesthetic induction with this herbal compound aversive for stingrays. These ventilatory responses are in line with the behavioral manifestations of hyperactivity and intense excitability observed in these eugenol-exposed animals, which were not attenuated during the phase of deep anesthesia. In this line of evidence, Barbas et al. (2021) demonstrated for juveniles of tambaqui (Colossoma macropomum), an Amazonian teleost species, that $65 \mathrm{mg} \mathrm{L}^{-1}$ eugenol induced the fish to immobilization (with loss of muscular tonus and reflex) in a time-dependent manner. However, electroencephalographic studies revealed that eugenol failed to depress the central nervous system (CNS), resulting in an intense neuronal excitatory condition. Thus, the evidence of the behavioral responses observed in juveniles of $P$. wallacei when exposed to eugenol corroborates the above cited results (Barbas et al. 2021), suggesting that stingrays had been immobilized (with a loss of muscle tonus) by the action of eugenol, without depressing their CNS function. These features led us to carefully consider the use of this herbal product as a safe anesthetic 
and draws our attention to its possible toxic action for animals when submitted to anesthetic practices. In a comparative perspective, the sequence of behavioral patterns shown by juveniles of $P$. wallacei under exposure to eugenol and EOLA was like those observed by Grusha (2005) for the marine stingray $R$. bonasus submitted to two distinct eugenol concentrations. On the other hand, the sharks T. semifasciata and M. californicus treated with an isoeugenol-based anesthetic (AQUI-S 20E®), a eugenol isomer, showed a prolonged induction time and more than one excitatory phase (Silbernagel and Yochem 2016). In this study, the stingrays anesthetized with eugenol showed long recovery times, a response that differs from that observed for viola ray, $Z$. brevirostris, anesthetized with $85 \mathrm{mg} \mathrm{L}^{-1}$ eugenol (Takatsuka et al. 2019). Conversely, juveniles of $P$. wallacei showed considerably shorter recovery times (4.2 min) after anesthesia, which are coincident to those observed in teleost fish (Marking and Meyer 1985; Keene et al. 1998), suggesting that eugenol can act differently in freshwater stingrays when compared to marine elasmobranchs.

The exposure of $P$. wallacei juveniles to $50 \mathrm{mg} \mathrm{L}^{-1}$ eugenol revealed that this concentration was not suited to deep anesthesia due to the long time to reach light or deep anesthesia (>10 min). The overexposure of $P$. wallacei to eugenol probably resulted in excessive absorption of this substance, culminating in $50 \%$ mortality during the recovery phase. On the other hand, the abrupt entry into the anesthesia phase and deaths recorded at concentrations above $75 \mathrm{mg} \mathrm{L}^{-1}$ eugenol increase the risk of anesthesia, cause deep respiratory depression and the anesthetic induction process must be stopped immediately as soon as deep anesthesia is observed (phase III).

When juveniles of $P$. wallacei were exposed to EOLA at concentrations of 50 and $100 \mu \mathrm{L} \mathrm{L}^{-1}$ they did not reach mild or deep anesthesia after $10 \mathrm{~min}$; therefore, these concentrations are not recommended to the practice of anesthesia for these stingrays. On the other hand, at concentrations over $300 \mu \mathrm{LL}^{-1}$ of this essential oil, neurological sequelae and subsequent deaths were observed after exposure, which may be related to a decrease in blood flow at the cerebral level during anesthesia. In bamboo sharks, Miller et al. (2005) observed signs of neurological alterations associated to intravenous administration of propofol. In the other concentrations of EOLA evaluated in this study, a uniform decline in the respiratory pattern was observed during anesthesia, with no obvious stressing effects, such as the initial high SF and sudden falls in ventilation observed with eugenol. This fact resulted in a better condition for physiological recovery after anesthesia, which was evidenced by the faster return to regular feeding and routine swimming after recovery from the anesthesia.

Considering that eugenol has a higher density (1.06) than that of EOLA (0.80), this physical property could be a relevant aspect when referring to bottom-dwelling elasmobranchs, like $P$. wallacei. Even when previously diluted with ethyl alcohol for its use (Neiffer and Stamper 2009), eugenol may be easily left at the bottom of the experimental aquarium, exacerbating its irritating effects when coming into direct contact with the eyes (causing evident eye retraction), skin (burns on the edges of the disc, and areas of focal necrosis on the body surface) and gills. The overall features of gill histology assessed in the present study confirms the detrimental effects of this anesthetic on the architecture of this tissue. The 
necrotizing characteristics promoted by eugenol in the gills led to impaired protection responses in the primary epithelium, promoting irreversible damage, such as ionocyte (chloride cell) apoptosis and lamellar necrosis. In contrast, despite promoting tissue irritation, EOLA triggered less irreversible damage and greater reversible changes in the protective response of the epithelium, such as hyperplasia and cellular hypertrophy. This increase in the proliferation and size of cells can lead to the fusion of lamellae, a response mechanism to protect the lamellar epithelium from direct contact with toxic agents; this increases the distance from the gill surface used for the diffusion of blood to inhibit the intake of substance from the surrounding environment (Heath 1987; Karan et al. 1998).

Another feasible explanation could be related to the inflammatory chemical mediators released from the injured tissue responsible for vasodilation and increased local vascular permeability. In this process, the increase in blood flow through capillary dilation, while allowing the arrival of defense cells, might predispose to edema and the formation of aneurysms (Pober and Sessa 2015). In our study, we observed the incidence of melanomacrophages in the blood vessels of branchial filaments of juveniles of $P$. wallacei exposed to both anesthetics. Melanomacrophages are cells with phagocytic activity having a considerable number of dark pigments inside, like melanin, lipofuscin and hemosiderin. These cells are commonly found in the stroma of lymphoid tissues of teleost fishes, such as the kidney and liver, and are associated with the immune response in organs like the gills, liver, kidney and spleen (Agius and Roberts 2003; Steinel and Bolnick 2017) and related inflammatory processes (Manrique et al. 2014). However, other functions associated with the natural physiological mechanisms of cell renewal, waste cleaning and collagen recycling (Gutierre et al. 2017), lipid deposition during fasting (Neyrão et al. 2019), and iron recycling from hemoglobin molecules (Wolke 1992; Passantino et al. 2005; Sales et al. 2017) have also been documented. Studies on elasmobranch species have been sporadic (Borucinska et al. 2009; Moraes et al. 2016) and inconclusive. In Potamotrygon motoro, the presence of these cells was recognized and associated with the immune response, acting as the site of antigen processing (Moraes et al. 2016), and with environmental pollution triggered by gold and oil exploitation in the occurrence area of this species in Peruvian territory (Ramos-Espinoza et al. 2017). However, in the present study, the arrival of melanomacrophages in the gills of $P$. wallacei exposed to concentrations of $100 \mu \mathrm{L}^{-1}$ eugenol and 175 $\mu \mathrm{L} \mathrm{L}^{-1}$ EOLA cannot be attributed entirely to the toxic effect of these anesthetics. The presence of this cell type surrounding the blood vessels of the gill filaments seems to be more associated with natural physiological processes, because they were only observed at intermediate concentrations, and since despite the most expressive changes evidenced in the epithelium at the highest concentrations of both anesthetics, this cell type was not found. Thus, further investigations are required to better understand the role of melanomacrophages in routine physiological and immunological responses in the gills and other tissues of freshwater stingrays.

The hematocrit values obtained in juveniles of $P$. wallacei were within the range recorded for this species under different environmental and experimental conditions (Brinn et al. 2012; Pastório 2014; Oliveira et al. 2016) and similar to those observed in marine stingray species, such as D. americana (Cain et al. 2004), A. rostrata (Routley et al. 2002; Speers-Roesch et al. 2012), Hypanus sabinus (Lambert et al. 2018) and 
Zearaja maugeana (Morash et al. 2020). In all these studies, a commonly observed characteristic was the lack of changes in this parameter in response to different types of stressors. Brinn et al. (2012) mentioned that the variables related to erythrogram did not function as suitable physiological indicators in the assessment of stress responses in juveniles of $P$. wallacei (= Potamotrygon cf. histrix) submitted to river transport. Our results corroborate this hypothesis and indicate that, at least for the tested concentrations, both eugenol and $L$. alba essential oil did not promote noticeable changes in this blood parameter in cururu stingrays, even after $48 \mathrm{~h}$ of recovery. In addition, the absence of statistical differences in the observed values of the plasma metabolite profile analyzed immediately after the anesthetic action and in the recovery $48 \mathrm{~h}$ later, especially glucose levels, is clearly indicative that the extent of contact with the different anesthetic concentrations of both eugenol and EOLA was not enough to promote changes in these blood physiological parameters, and hence do not interfere in the overall homeostasis of $P$. wallacei juveniles. These findings are in line with previous results for the same species exposed to anesthesia (Frick et al. 2012) or different types of stressors, like transport (Brinn et al. 2012; Ariotti et al. 2021) and progressive hypoxia (Pastório 2014).

On the other hand, the inability of these anesthetics to produce changes in the plasma lactate levels contrast with previous studies conducted with other elasmobranch species anesthetized with eugenol or its isomer, the isoeugenol. In Australian tiger sharks Cephaloscyllium laticeps, sedated with an anesthetic derived from clove oil (AQUI-S® isoeugenol, New Zealand Ltd.), the mean plasma lactate levels were also significantly higher than those of untreated sharks (Frick et al. 2012), and like $P$. wallacei, no significant differences in plasma glucose were observed between the treatment groups. Usually, sharks alter blood parameters (like hematocrit, $\mathrm{pH}$, lactate, and glucose levels) only when submitted to vigorous and intense physical exercise (Skomal 2007; Frick et al. 2010; Brooks et al. 2012). In juveniles of Carcharhinus taurus, lactate levels remained significantly higher up to $12 \mathrm{~h}$ after capture stress (Kneebone et al. 2013). In a similar approach, Fuller et al. (2020) found that individuals of the Atlantic sharpnose shark (Rhizoprionodon terraenovae) showing higher lactate levels in blood after capture stress also exhibited lower clinical patterns of behavior required for safe release.

\section{Conclusions}

In the current study, although the blood responses were similar between the two anesthetics, the noticed oscillating effects on spiracular frequency (ventilation rate) during anesthetic administration with eugenol, allied with a long excitatory stage during anesthetic induction and a faster return, in addition to the extent of lesions observed in both external disc and gill lamellas, makes the use of this substance somewhat risky for juveniles of $P$. wallacei. On the other hand, concerning the better ventilatory pattern, the unchanging levels of blood lactate, combined with a lower degree of histopathological changes observed in the gill apparatus, this study recommends the use of EOLA for anesthesia of $P$. wallacei stingrays during short-term anesthetic procedures. In this sense, a concentration of $200 \mu \mathrm{L} \mathrm{L}^{-1}$ is indicated since it required a shorter time to achieve anesthesia and provided a subsequent safe recovery. 


\section{Declarations}

Acknowledgements

Authors tanks the professional fisherman from the Daracuá Community (Barcelos, Amazonas, Brazil) for their relevant support in collecting the juvenile stingrays. We also are grateful to the staff of the Laboratories of Animal Physiology and Functional Morphology for the analysis of blood constituents and gill histology, respectively.

\section{AUTHOR DECLARATIONS}

\section{Funding}

This work was, in part, supported by a grant from the Brazilian National Council for Scientific and Technological Development (Conselho Nacional de Desenvolvimento Científico e Tecnológico - CNPq) to JLM (process number 484566/2013-0). B. Baldisserotto received a research fellowship from CNPq (process 301225/2017-6).

\section{Declaration of competing interests}

The authors declare that they have no competing interests.

\section{Data Availability Statement}

The data that support the findings of this study are available from the corresponding author upon reasonable request.

\section{Authorship Contribution Statement}

Conceptualization: [Cristiano Lopes de Lima, Bernardo Baldisserotto, Jaydione Luiz Marcon]; Methodology: [Cristiano Lopes de Lima, Denise Schmidt, Bernardo Baldisserotto, Jaydione Luiz Marcon]; Formal analysis and investigation: [Cristiano Lopes de Lima, Ruben Dario Morales-Gamba, Thiago Santana Malcher Neto, José Fernando Marques Barcellos, Berta Maria Heinzmann, Denise Schmidt, Baldisserotto, Jaydione Luiz Marcon]; Writing - original draft preparation: [Cristiano Lopes de Lima, Ruben Dario Morales-Gamba, Thiago Santana Malcher Neto]; Writing - review \& editing: [Berta Maria Heinzmann, Denise Schmidt, Bernardo Baldisserotto, Jaydione Luiz Marcon]; Project administration: [Jaydione Luiz Marcon]; Funding acquisition: [Bernardo Baldisserotto, Jaydione Luiz Marcon]; Resources: [Bernardo Baldisserotto, Jaydione Luiz Marcon]; Supervision: [Jaydione Luiz Marcon].

Ethics approval/declarations (also included in Material and Methods section)

This work followed all the legal requirements for capture and manipulation of free-living cururu stingrays, which include a permanent license for collection of zoological material, registered (SISBIO No. 18285-1) at the Chico Mendes Institute for Conservation and Biodiversity (ICMBio), linked to the Ministry of the 
Environment, and the approval of the Ethics Committee on the Use of Animals in Research of the Federal University of Amazonas (registry number \#002/2017-CEUA/UFAM) that was developed in accordance with the rules of ethical principles for animal experimentation approved by the Brazilian Council for the Control of Animal Experimentation (CONCEA).

\section{Consent to participate}

All authors agreed to participate as integrant members of this study and are equally responsible for all aspects of the work related to its accuracy and integrity.

\section{Consent for publication}

All authors read the final version of this manuscript and approved their names to be included in the publication process.

\section{References}

1. Agius C, Roberts RJ (2003) Review: Melano-macrophage centers and their role in fish pathology. J Fish Dis, 26: 499-509. doi: https://doi.org/10.1046/j.1365-2761.2003.00485.x

2. Anderson WG (2012) The endocrinology of 1a-hydroxycorticosterone in elasmobranch fish: a review. Comp Biochem Physiol A Mol Integr Physiol 162(2):73-80. https://doi.org/10.1016/j.cbpa.2011.08.015

3. Araújo MLG (1998) Biologia reprodutiva e pesca de Potamotrygon sp. (Chondrichthyes, Potamotrygonidae), no médio Rio Negro, Amazonas. Master Thesis, INPA (Instituto Nacional de Pesquisas da Amazônia), Manaus

4. Ascenção VL, Filho VEM (2013) Extração, caracterização química e atividade antifúngica de óleo essencial Syzygium aromaticum (cravo da índia). Capa v. 20. especial. http://dx.doi.org/10.18764/2178-2229.v20n.especialp137-144

5. Balasch JC, Tort L (2019) Netting the stress responses in fish. Front Endocrinol. https://doi.org/10.3389/fendo.2019.00062

6. Barbas LAL, Torres MF, Costa BMPA, Feitosa MJM, Maltez LC, Amado LL, Toda YPS, Batista PS, Cabral DAC, Hamoy M (2020) Eugenol induces body immobilization yet evoking an increased neuronal excitability in fish during short-term baths. Aquat Toxicol 231:105734. https://doi.org/10.1016/j.aquatox.2020.105734

7. Borucinska JD, Kotran K, Shackett M, Barker T (2009) Melanomacrophages in three species of freeranging sharks from the northwestern Atlantic, the blue shark Prionacae glauca (L.), the shortfin mako, Isurus oxyrhinchus Rafinesque, and the thresher, Alopias vulpinus (Bonnaterre). J Fish Dis 32(10):883-891. doi:10.1111/j.1365-2761.2009.01067.x

8. Brinn RP, Marcon JL, Mccomb DM, Gomes LC, Abreu JS, Baldisserotto B (2012) Stress responses of the endemic freshwater cururu stingray (Potamotrygon cf. histrix) during transportation in the 
Amazon region of the Rio Negro. Comp Biochem Physiol Part A 162(2):139-145. doi:10.1016/j.cbpa.2011.07.004

9. Brooks EJ, Mandelman JW, Sloman KA, Liss S, Danylchuk AJ, Cooke SJ, Skomal GB, Philipp DP, Sims DW, Suski CD (2012) The physiological response of the Caribbean reef shark (Carcharhinus perezi) to longline capture. Comp Biochem Physiol A Mol Integr Physiol Part A 162(2):94-100. doi:10.1016/j.cbpa.2011.04.012

10. Cain DK, Harms CA, Segars A (2004) Plasma biochemistry reference values of wild caught southern stingrays (Dasyatis americana). J Zoo Wild Med 35(4):471-476. https://doi.org/10.1638/03-107

11. Carvalho MR, Rosa RS, Araújo MLG (2016) A new species of Neotropical freshwater stingray (Chondrichthyes: Potamotrygonidae) from the Rio Negro, Amazonas, Brazil: the smallest species of Potamotrygon. Zootaxa 4107(4):566-586. doi:https://doi.org/10.11646/zootaxa.4107.4.5

12. Cunha MA, Barros CM, Garcia LO, Veeck APL, Heinzmann BM, Loro VL, Emanuelli T, Baldisserotto B (2010) Essential oil of Lippia alba, a new anesthetic for silver catfish, Rhamdia quelen. Aquaculture 306:403-406. https://doi.org/10.1016/j.aquaculture.2010.06.014

13. Cunha MA, Silva BF, Delunardo FAC, Benovit SC, Gomes LC, Heinzmann BM, Baldisserotto B (2011) Anesthetic induction and recovery of Hippocampus reidi exposed to the essential oil of Lippia alba. Neotrop Ichthyol 9(3):683-688. http://dx.doi.org/10.1590/S1679-62252011000300022

14. Duncan PW, Costa OTF, Sakuragui MM, Fernandes MN (2010b) Functional Morphology of the Gill in Amazonian Freshwater Stingrays (Chondrichthyes: Potamotrygonidae): Implications for Adaptation to Freshwater. Physiol Biochem Zool 83(1):19-32. doi:10.1086/605458

15. Duncan WP, Silva NF, Fernandes MN (2011) Mitochondrion-rich cells distribution, Na+/K+-ATPase activity and gill morphometry of the Amazonian freshwater stingrays (Chondrichthyes: Potamotrygonidae). Fish Physiol Biochem 37(3):523-531. doi:10.1007/s10695-010-9454-z

16. Frick LH, Reina RD, Walker TI (2009) The Physiological Response of Port Jackson Sharks and Australian Swellsharks to Sedation, Gill-Net Capture, and Repeated Sampling in Captivity. N Am J Fish Manag 29:127-139. DOI:10.1577/M08-031.1

17. Frick LH, Reina RD, Walker TI (2010) Stress related physiological changes and post-release survival of Port Jackson sharks (Heterodontus portusjacksoni) and gummy sharks (Mustelus antarcticus) following gill-net and longline capture in captivity. J Exp Mar Biol Ecol 385(1-2):29-37. https://doi.org/10.1016/j.jembe.2010.01.013

18. Frick LH, Walker TI, Reina RD (2012) Immediate and delayed effects of gill-net capture on acid-base balance and intramuscular lactate concentration of gummy sharks, Mustelus antarcticus. Comp Biochem Physiol A Mol Integr Physiol 162(2):88-93. https://doi.org/10.1016/j.cbpa.2011.02.023

19. Fuller L, Stell E, Leary C, Parsons G (2020) Circulating adrenocorticotropic hormone levels, lactate levels, hematocrit and osmolality in relation to capture stress in Atlantic sharpnose sharks, Rhizoprionodon terraenovae. Comp Biochem Physiol A Mol Integr Physiol. https://doi.org/10.1016/j.cbpa.2020.110655 
20. Goldenfarb PB, Bowyer FP, Hall E, Brosious E (1971) Reproducibility in the hematology laboratory: the microhematocrit determination. Am J Clin Pathol 56(1):35-39. doi:10.1093/ajcp/56.1.35

21. Gutierre RC, Jared C, Antoniazzi MM, Coppi AA, Egami MI (2017) Melanomacrophage functions in the liver of the caecilian Siphonops annulatus. J Anat 232(3):497-508. doi:10.1111/joa.12757

22. Graham JB, Heididewar NC, Lai WRL, Arce SM (1990) Aspects of shark swimming performance determined using a large water tunnel. J Exp Biol 151(1):175192 https://doi.org/10.1242/jeb.151.1.175

23. Grusha DS (2005) Investigation of the life history of the cownose ray, Rhinoptera bonasus (Mitchill 1815). Dissertation, The College of William and Mary, Williamsburg, Virginia. 116pp

24. Haddad V Jr, Neto DG, Neto JBP, Marques FPL, Barbaro KC (2004) Freshwater stingrays: study of epidemiologic, clinic and therapeutic aspects based on 84 envenomings in humans and some enzymatic activities of the venom. Toxicon 48:287-294. doi:10.1016/j.toxicon.2003.12.006

25. Heath AG (1987) Water pollution and fish physiology. CRC Press, Boca Raton

26. Hennebelle T, Sahpaz S, Joseph H, Bailleul F (2008) Ethnopharmacology of Lippia alba. J Ethnopharmacol 116(2):211-222. doi:10.1016/j.jep.2007.11.044

27. Hohlenwerger JC, Copatti CE, Sena AC, Couto RD, Baldisserotto B, Heinzmann BM, Caron BO, Schmidt D (2016) Could the essential oil of Lippia alba provide a readily available and cost-effective anaesthetic for Nile tilapia (Oreochromis niloticus)? Mar Freshw Behav Physiol. 49, 119-126. https://doi.org/10.1080/10236244.2015.1123869

28. Hoseini SM, Mirghaed AT, Yousefi M (2019) Application of herbal anaesthetics in aquaculture. Rev Aquac 11:550-564. https://doi.org/10.1111/raq.12245

29. Hove JR, Moss SA (1997) Effect of MS-222 on response to light and rate of metabolism of the little skate Raja erinacea. Mar Biol 128:579-583. https://doi.org/10.1007/s002270050124

30. Husen A, Sharma S (2014) Efficacy of anesthetics for reducing stress in fish during aquaculture practices-a review. J Sci Eng Technol Kathmandu University 10(1):104-123

31. Idler DR, Truscott B (1966) 1a-hydroxycorticosterone from cartilaginous fish: a new adrenal steroid in blood. J Fish Bd Canada 23:615-619. https://doi.org/10.1139/f66-053

32. Karan V, Vitorovic S, Tutundzic V, Poleksic V (1998) Functional enzymes activity and gill histology of carp after copper sulfate exposure and recovery. Ecotoxicol Environ Saf 40:49-55. doi:10.1006/eesa.1998.1641

33. Keene JL, Noakes DLG, Moccia RD, Soto CG (1998) The efficacy of clove oil as an anaesthetic for rainbow trout, Oncorhynchus mykiss (Walbaum). Aquac Res 29(2):89-101. https://doi.org/10.1046/j.1365-2109.1998.00927.x

34. Kimura LF, Santos-Neto M, Barbaro KC, Picolo G (2018) Potamotrygon motoro stingray venom induces both neurogenic and inflammatory pain behavior in rodents. Toxicon 150:168-174. DOI:10.1016/j.toxicon.2018.05.018 
35. Kneebone J, Chisholm J, Bernal D, Skomal G (2013) The physiological effects of capture stress, recovery, and post-release survivorship of juvenile sand tigers (Carcharias taurus) caught on rod and reel. Fish Res 147:103-114. https://doi.org/10.1016/j.fishres.2013.04.009

36. Lambert FN, Treberg JR, Anderson WG, Brandt C, Evans AN (2018) The physiological stress response of the Atlantic stingray (Hypanus sabinus) to aerial exposure. Comp Biochem Physiol A Mol Integr Physiol, 219-220, 38-43. doi:10.1016/j.cbpa.2018.02.009

37. Lécu A, Herbert R, Coulier L, Tirmarche D, Hénard S (2017) Anesthetic trials using various species of elasmobranch at Nausicaá Aquarium. In: Smith M, Warmolts D, Thoney D, Hueter R, Murray M, Ezurra $J$ (eds) The Elasmobranch husbandry manual II: Recent advances in the care of sharks, rays and their relatives. Special publication of the Ohio Biological Survey, Columbus, pp 339-348

38. Lorenzini H, Matos FJA (2008) Plantas medicinais do Brasil: nativas e exóticas. Instituto Plantarum, São Paulo, Brasil

39. Manrique WG, Claudiano GS, Petrillo TR, Castro MP, Figueiredo MAP, Belo MAA, Moraes JRE, Moraes FR (2014) Response of splenic melanomacrophage centers of Oreochromis niloticus (Linnaeus, 1758) to inflammatory stimuli by BCG and foreign bodies. J Appl Ichthyol 30(5):1001-1006. https://doi.org/10.1111/jai.12445

40. Marshall H, Field L, Afiadata A, Sepulveda C, Skomal G, Bernal D (2012) Hematological indicators of stress in longline-captured sharks. Comp Biochem Physiol A Mol Integr Physiol 162(2):121-129. https://doi.org/10.1016/j.cbpa.2012.02.008

41. Marking LL, Meyer FP (1985) Are better fish anesthetics needed in fisheries? Fisheries, 10: 2-5. https://doi.org/10.1577/1548-8446(1985)010<0002:ABANIF>2.0.C0;2

42. Miller SM, Mitchell MA, Heatley JJ, Wolf T, Lapuz F, Lafortune M, Smith JA (2005) Clinical and cardiorespiratory effects of propofol in the spotted bamboo shark (Chylloscyllium plagiosum). J Zoo Wildl Med 36(4):673-676. DOI:10.1638/04034.1

43. Moraes JRE, Agnaga YJ, Viadanna P, Moraes FR (2016) A histology-based study in apparently healthy wild freshwater stingrays Potamotrygon motoro. Comp Clin Path 25:165-168. DOI $10.1007 /$ s00580-015-2162-4

44. Morash AJ, Lyle JM, Currie S, Bell JD, Stehfest KM, Semmens JM (2020) The endemic and endangered Maugean Skate (Zearaja maugeana) exhibits short-term severe hypoxia tolerance. Conserv Physiol 8(1):coz105. doi.org/10.1093/conphys/coz105

45. Mylniczenko DN, Clauss TM, Stamper MA (2014) Elasmobranch and holocephalans. In: West G, Heard DJ, Caulkett N, Blackwell W (Eds) Zoo animal and wildlife immobilization and anesthesia, second edition. blackwell publishing professional, Ames, lowa. pp 261-302

46. Neiffer DL, Stamper MA (2009) Fish sedation, anesthesia, analgesia, and euthanasia: considerations, methods, and types of drugs. ILAR J 50(4):343-360. doi:10.1093/ilar.50.4.343

47. Neyrão I, Conrado ALV, Takatsuka V, Bruno CEM, Azevedo VG (2019) Quantification of liver lipid deposition and melano-macrophages in lesser guitarfish Zapteryx brevirostris submitted to different feeding cycles. Comp Clin Path 28 (1), https://doi.org/10.1007/s00580-019-02953-8 
48. Oliveira AT, Santos MQC, Araujo MLG, Lemos JRG, Sales RSA, Pantoja-Lima J, Tavares-Dias M, Marcon JL (2016) Hematological parameters of three freshwater stingray species (Chondrichthyes: Potamotrygonidae) in the middle Rio Negro, Amazonas state. Biochem Syst Ecol 69:33-40. https://doi.org/10.1016/j.bse.2016.07.002

49. Oliveira AT, Araujo MLG, Lemos JRG, Santos MQC, Pantoja-Lima J, Aride PHR, Tavares-Dias M, Marcon JL (2017) Ecophysiological interactions and water-related physicochemical parameters among freshwater stingrays. Braz J Biol 77:616-621. https://doi.org/10.1590/1519-6984.01816

50. Passantino L, Cianciotta A, Jirillo F, Carrassi M, Jirillo E, Passantino GF (2005) Lymphoreticular system in fish: Erythrocyte-mediated immunomodulation of macrophages contributes to the formation of melanomacrophage centers. Immunopharmacol Immunotoxicol 27(1):147-161. DOI:10.1081/IPH-200051766

51. Pastório PCC (2014) Respostas fisiológicas da arraia cururu, Potamotrygon cf. histrix à hipóxia gradual. Master Thesis. Universidade Federal do Amazonas, Manaus, Amazonas

52. Pober JS, Sessa WC (2015) Inflammation and the blood microvasculas system. J List Cold Spring Harb Perspect Biol 7(1):a016345. doi:10.1101/cshperspect.a016345

53. Raines JA, Clancy MM (2009) Sedation by orally administered ketamine in goldfish, Carassius auratus; hybrid striped bass, Morone hybrid saxatilis $\times$ M. chrysops; and ocellated river stingray. Potamotrygon motoro J World Aquac Soc 40(6):788-794. https://doi.org/10.1111/j.17497345.2009.00299.x

54. Ramos-Espinoza FC, Chuquipiondo CT, Serrano-Martínez EM (2017) Histopathological study in wild freshwater stingrays Potamotrygon motoro in the Peruvian Amazon. Comp Clin Pathol 26:525-529. https://doi.org/10.1007/s00580-017-2411-9

55. Routley MH, nilsson GE, Renshaw GMC (2002) Exposure to hypoxia primes the respiratory and metabolic responses of the epaulette shark to progressive hypoxia. Comp Biochem Physiol A Mol Integr physiol 131(2):313-321. doi:10.1016/s1095-6433(01)00484-6

56. Ruiz-Jarabo I, Barragán-Méndez C, Jerez-Cepa I, Fernández-Castro M, Sobrino I, Mancera JM, Aerts J (2019) Plasma 1a-hydroxycorticosterone as biomarker for acute stress in catsharks (Scyliorhinus canicula). Front Physiol 10:1217. https://doi.org/10.3389/fphys.2019.01217

57. Sales CF, Silva RF, Amaral MGC, Domingos FFT, Ribeiro RIMA, Thomé RG, Santos HB (2017) Comparative histology in the liver and spleen of three species of freshwater teleost. Neotrop Ichthyol, 15(1) https://doi.org/10.1590/1982-0224-20160041

58. Silbernagel C, Yochem $P(2016)$ Effectiveness of the Anesthetic Aqui-s $\AA 20 \mathrm{e}$ in marine finfish and elasmobranchs. J Wildl Dis 52(2s):S96-S103. DOI:10.7589/52.2S.S96

59. Silva NJJ, Ferreira KRC, Pinto RNL, Aird SD (2015) A severe accident caused by an ocellate river stingray (Potamotrygon motoro) in central Brazil: How well do we really understand stingray venom chemistry, envenomation, and therapeutics?" toxins 7(6): 2272-2288. https://doi.org/10.3390/toxins7062272 
60. Silva GA, Poscai NA, Casas ALS (2020) Injuries caused by freshwater stingrays in the western amazon: folk medicine and beliefs. Ethnobiology Letters v 11(1):1-13.

https://doi.org/10.14237/ebl.11.1.2020.1586

61. Skomal GB (2007) Evaluating the physiological and physical consequences of capture on postrelease survivorship in large pelagic fishes. Fish Manag Ecol 14(2):81-89.

https://doi.org/10.1111/j.1365-2400.2007.00528.x

62. Speers-Roesch B, Richards JG, Brauner CJ, Farrell AP, Hickey AJR, Wang YS, Renshaw GMV (2012) Hypoxia tolerance in elasmobranchs. I. Critical oxygen tension as a measure of blood oxygen transport during hypoxia exposure. J Exp Biol 215:103-114. doi:10.1242/jeb.059667

63. Sneddon LU (2012) Clinical anesthesia and analgesia in fish. J Exot Pet Med 21(1):32-43

64. Souza CF, Baldissera MD, Baldisserotto B, Heinzmann BM, Martos-Sitcha JA, Mancera JM (2019a) Essential oils as stress-reducing agents for fish aquaculture: A review. Front Physiol 10:785. https://doi.org/10.3389/fphys.2019.00785

65. Souza CF, Descovi S, Baldissera MD, Bertolin K, Bianchini AE, Mourao RHV, Schmidt D, Heinzmann BM, Antoniazzi A, Baldisserotto B, Martinez-Rodriguez G (2019b) Involvement of HPI-axis in anesthesia with Lippia alba essential oil citral and linalool chemotypes: gene expression in the secondary responses in silver catfish. Fish Physiol Biochem 45:155-166. doi:10.1007/s10695-0180548-3

66. Stamper MA (2004) Immobilization of Elasmobranchs In: Smith M, Warmolts D, Thoney D, Hueter R. The Elasmobranch Husbandry Manual. Ohio Biological Survey, Inc. Columbus, Ohio. pp. 281-295

67. Steinel NC, Bolnick DI (2017) Melanomacrophage centers as a histological indicator of immune Function in Fish and Other Poikilotherms. Front Immunol, . Mini Review published: 17 July 2017 doi: 10.3389/fimmu.2017.00827

68. Takatsuka V, Costa DGC, Oliveira NY, Sanches EG, Azevedo VG (2019) Use of eugenol for anesthesia of lesser guitarfish Zapteryx brevirostris (Rhinobatidae). Braz J Biol 79(3):516-520. doi:10.1590/1519-6984.186755

69. Toni C, Becker AG, Simões LN, Pinheiro CG, Lima SL, Heinzmann BM, Caron BO, Baldisserotto B (2014) Fish anesthesia: effects of the essential oils of Hesperozygis ringens and Lippia alba on the biochemistry and physiology of silver catfish (Rhamdia quelen). Fish Physiol Biochem 40(3):701714. doi:10.1007/s10695-013-9877-4

70. Wheaton CJ, Mylniczenko ND, Rimoldi JM, Gadepalli RSVS, Hart R, O'Hara BR, Evans AN (2018) Challenges, pitfalls and surprises: development and validation of a monoclonal antibody for enzyme immunoassay of the steroid 1a-hydroxycorticosterone in elasmobranch species. Gen Comp Endocrinol 265:83-89. doi:10.1016/j.ygcen.2018.01.028

71. Wendelaar-Bonga SEW (1997) The stress response in fish. Physiol Rev 77:591-625. https://doi.org/10.1152/physrev.1997.77.3.591

72. Wolke RE (1992) Piscine macrophage aggregates: A review. Annu Rev Fish Dis 2:91-108. https://doi.org/10.1016/0959-8030(92)90058-6 
73. Zahl IH, Samuelsen O, Kiessling A (2012) Anaesthesia of farmed fish: implications for welfare. Fish Physiol Biochem 38:201-218. doi:10.1007/s10695-011-9565-1

\section{Figures}
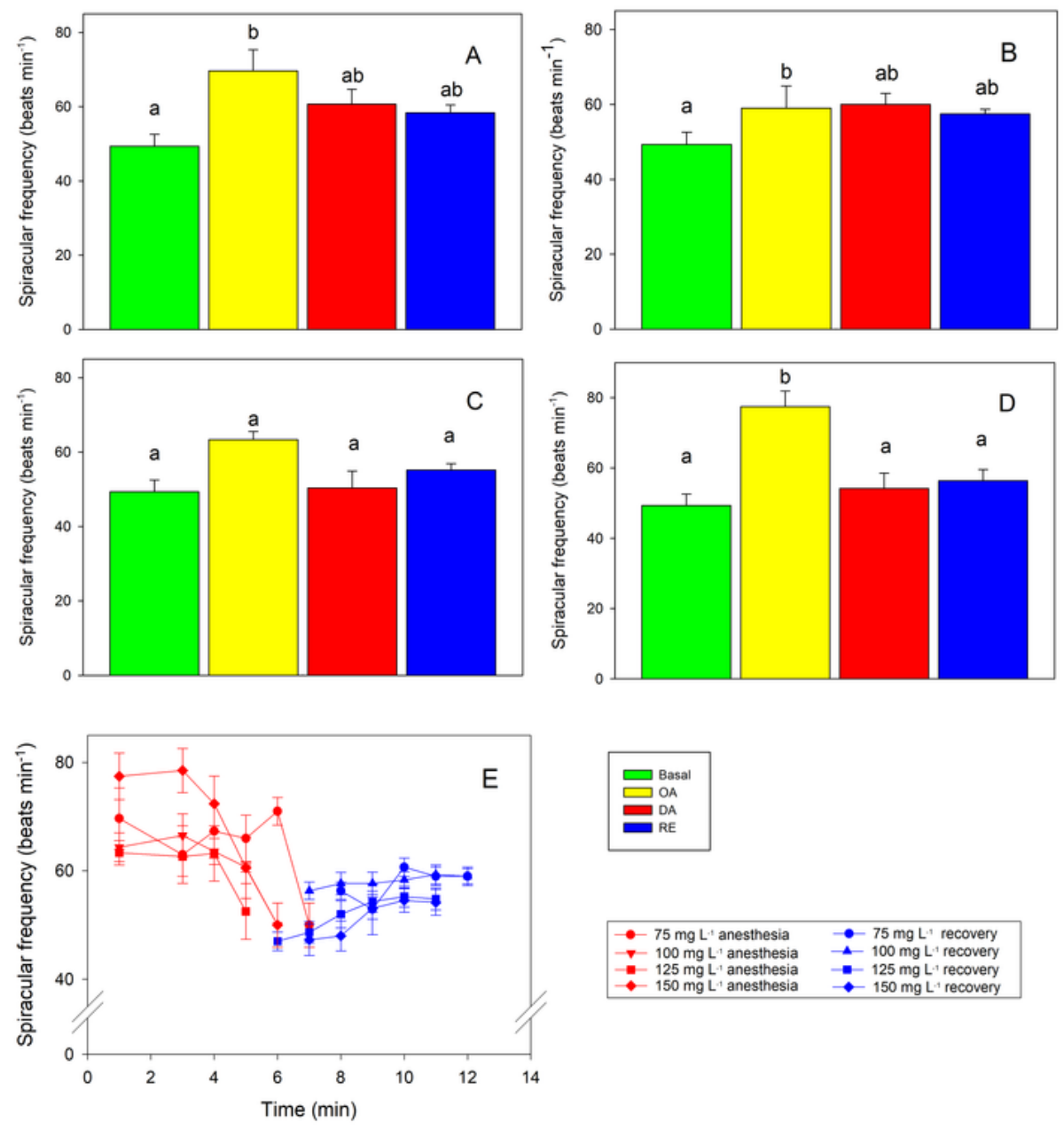

\section{Figure 1}


Spiracular frequency (SF) in juveniles of P. wallacei $(n=12)$ at different stages of anesthesia with different concentrations of eugenol: (A) $75 \mu \mathrm{L} \mathrm{L-1}$, (B) $100 \mu \mathrm{L} \mathrm{L-1,} \mathrm{(C)} 125 \mu \mathrm{L} \mathrm{L-1,} \mathrm{(D)} 150 \mu \mathrm{L} \mathrm{L-1}$. (E) Illustrative time response (minute to minute) profiles of SF through anesthesia induction (symbols in red) and recovery (symbols in blue) with different concentrations of eugenol (no statistical analysis was applied). Basal: stingrays not handled and not exposed; OA: onset of anesthesia: DA: deep anesthesia; RE: recovery $48 \mathrm{~h}$ later. Different letters indicate significant difference $(p<0.05)$ between stages.
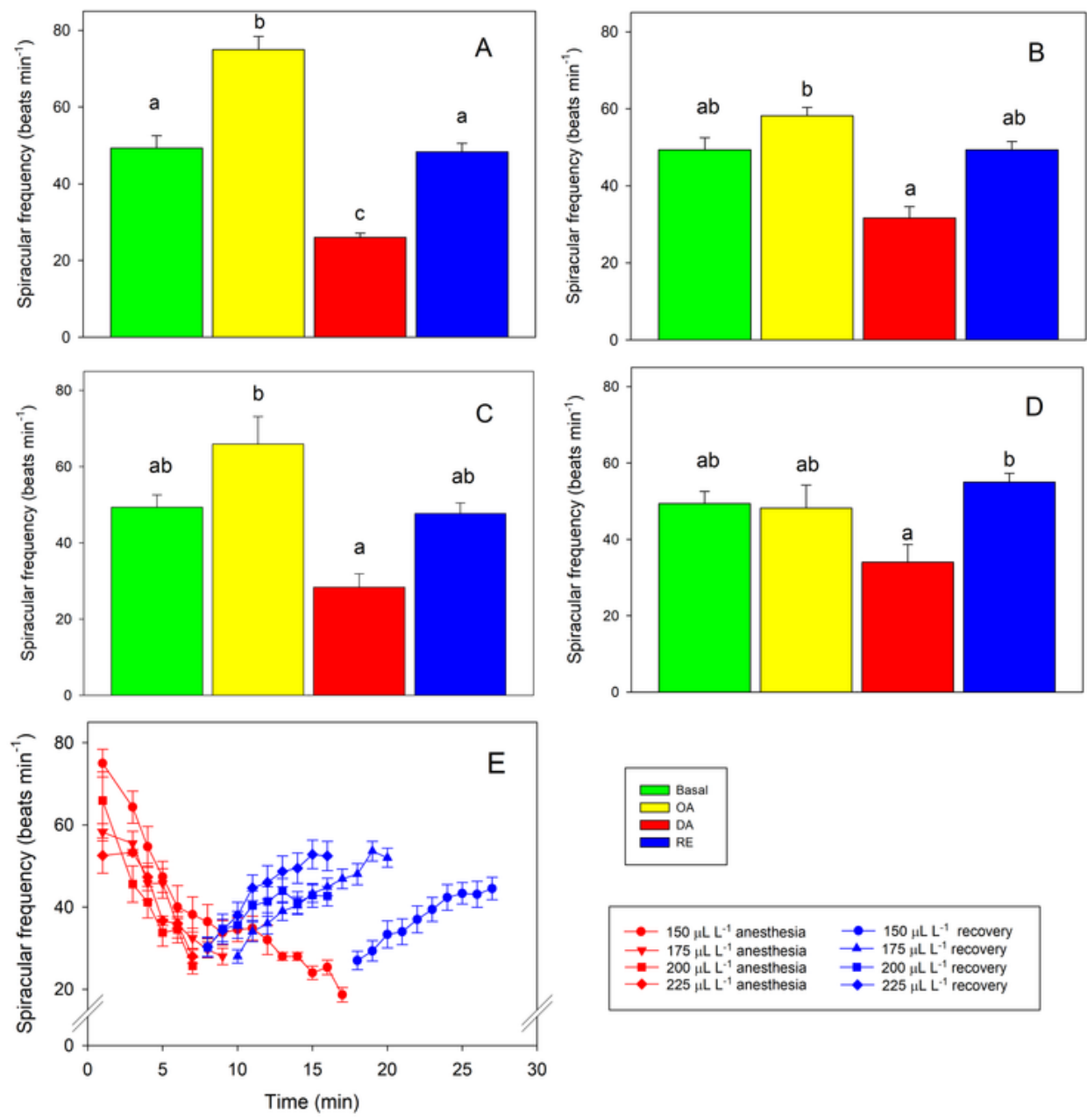
Spiracular frequency (SF) in juveniles of P. wallacei $(n=12)$ at different stages of anesthesia with different concentrations of EOLA: (A) $150 \mu \mathrm{L} \mathrm{L-1,} \mathrm{(B)} 175 \mu \mathrm{L} \mathrm{L-1,} \mathrm{(C)} 200 \mu \mathrm{L} L-1$, (D) $225 \mu \mathrm{L} \mathrm{L}-1$. (E) Illustrative time response (minute to minute) profiles of SF through anesthesia induction (symbols in red) and recovery (symbols in blue) with different concentrations of EOLA (no statistical analysis was applied). Basal: stingrays not handled and not exposed; OA: onset of anesthesia: DA: deep anesthesia; RE: recovery $48 \mathrm{~h}$ later. Different letters indicate significant difference $(p<0.05)$ between stages.

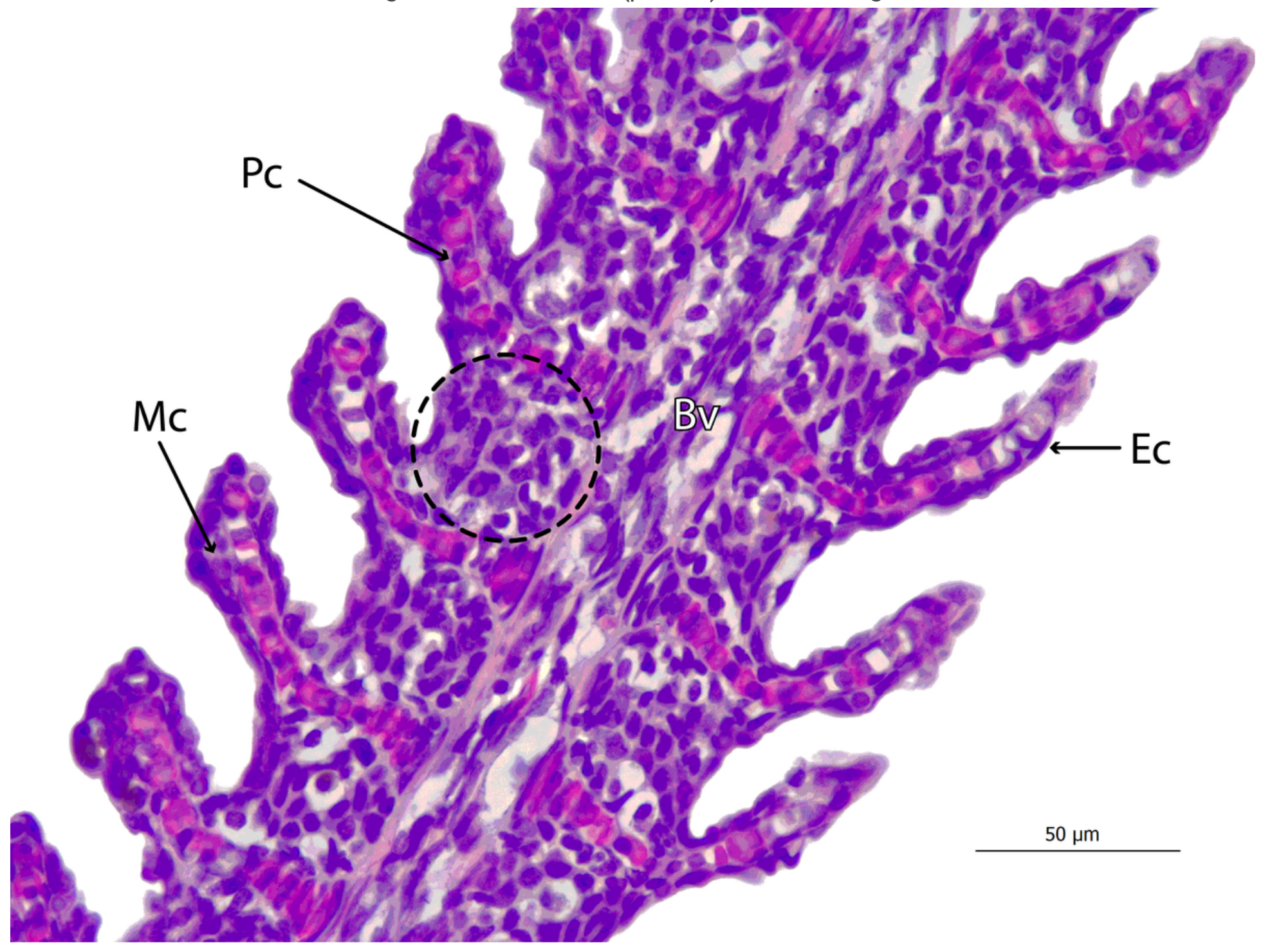

\section{Figure 3}

Gill filaments of the Potamotrygon wallacei control group showing a primary lamella (PI) with central blood vessel (BV) carrying secondary lamellae (SI); epithelial cell (Ec); mucous cell (Mc); pillar cell (PC) and ionocytes (black dotted circle). Hematoxylin-Eosin stain. 

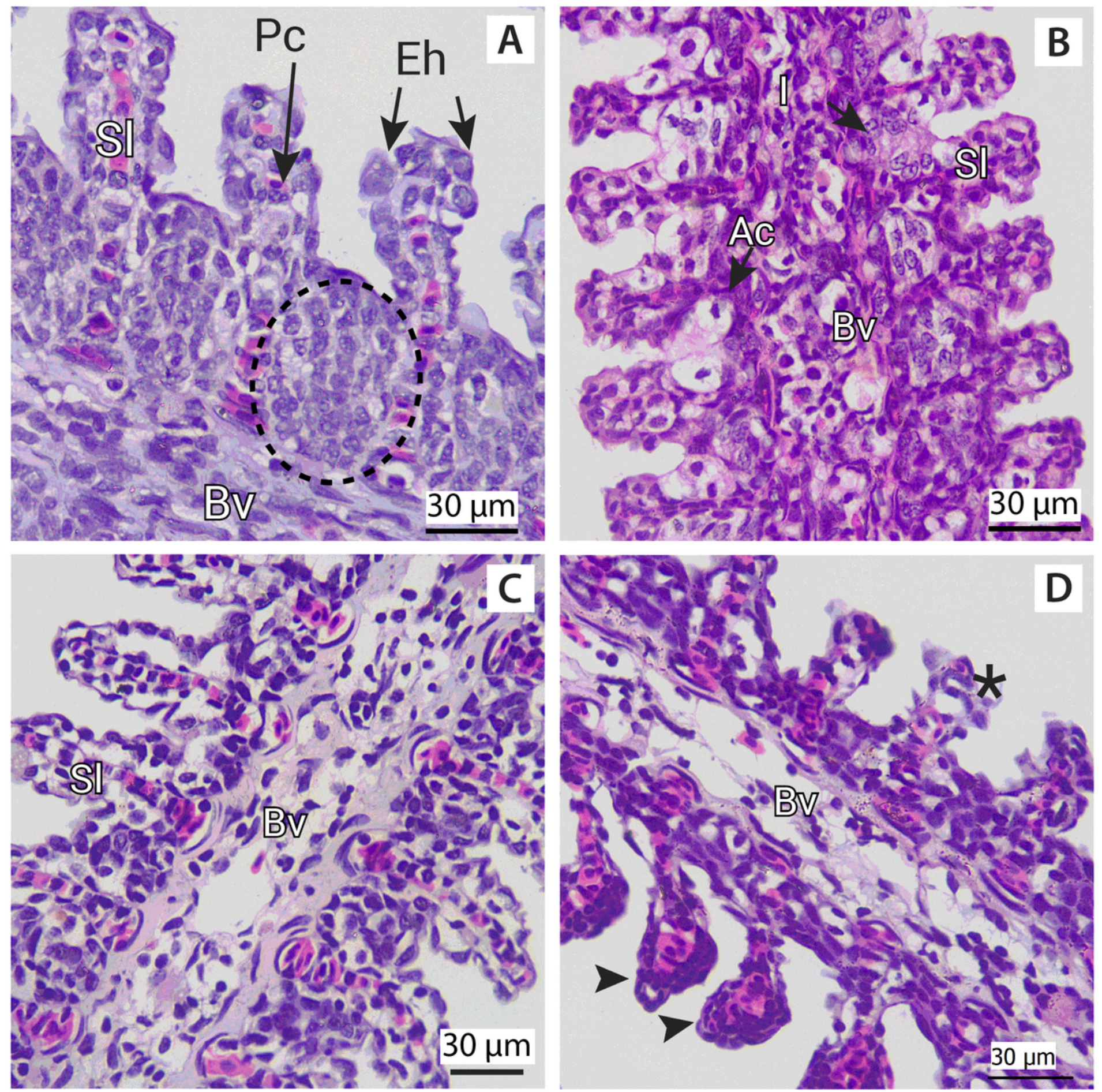

Figure 4

Histopathological changes of Potamotrygon wallacei gills exposed to eugenol; A) Hyperplasia in ionocytes (black dotted circle) and hypertrophy of epithelium cells of secondary lamellae (Eh); (B) apoptotic chloride cells (Ac) (C) filament epithelial detachment (Ed); (D) lamellar aneurysm (arrowheads) with epithelial cell hyperplasia (Eh) and epithelial rupture (asterisk); central blood vessel (Bv); ionocytes (I); secondary lamellae (SI). Hematoxylin-Eosin stain. 

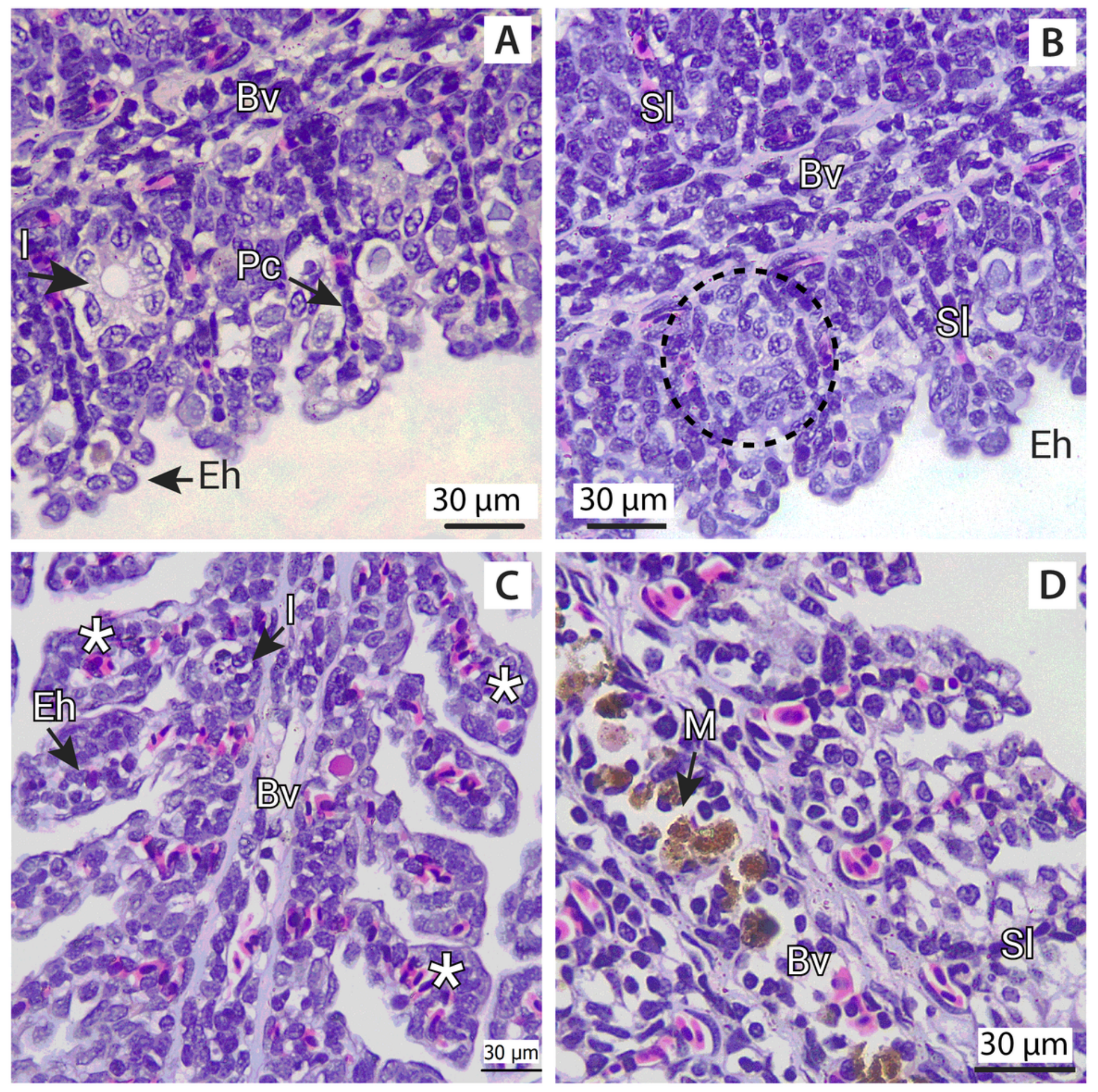

Figure 5

Histopathological changes of Potamotrygon wallacei gills exposed to the essential oil of Lippia alba (EOLA). A and B) showing hypertrophy of the epithelial cells of secondary lamellae (Eh) with evident laminar fusion; B) ionocyte hyperplasia C) lamellar aneurysm. (*); D) presence of melanomacrophages (M) in the central blood vessel (Bv); ionocytes (I); secondary lamellae (SI). Hematoxylin-Eosin stain.

\section{Supplementary Files}


This is a list of supplementary files associated with this preprint. Click to download.

- Fig.SI1.tif

- Fig.SI2.tif 